\title{
Amerikan Post-Apokaliptik Bilimkurgu Sinemasında Kıyamet İdeolojisi (1924-2000)1
}

\author{
Mikail BOZ23 \\ Dilek TAKIMCI ${ }^{4}$
}

\begin{abstract}
$\ddot{0 z}$
Bu çalışma geleceğe dönük büyük çaplı küresel korkuların sinemada, 2000 öncesi Amerikan post-apokaliptik bilimkurgu filmlerinde nasıl temsil edildiğine odaklanmaktadır. Makale, temsil edilen ideolojilerin değişim ve dönüşümlerini anlamayı, kıyamet ideolojisinin ne türden bir gelecek tasavvuru olarak şekillendiğini göstermeyi amaçlamaktadır. Bu çerçevede ABD'de üretilmiş olan post-apokaliptik bilimkurgu filmleri tarihsel ve ideolojik bir perspektifle araştııılmıştır. Türün ortaya çıktığı yirminci yüzyılın ilk yarısındaki öncül filmler belirtildikten sonra, filmler türün yükselişe geçtiği İkinci Dünya Savaşı'ndan sonra onar yıllık periyotlarla incelenmiştir. Bu zaman aralıklarında öne çıkan tema ve motifler, Klaus Koch'un tanımladığı kıyamet ideolojisi kavramı çerçevesinde, L. Giannetti'nin ideolojik film analizi yöntemiyle çözümlenmiştir. Bu yolla türün genel özellikleri ve uylaşımları tarihsel olarak filmler izlenerek ve betimlenerek ortaya konmuştur. Sonuç olarak her onar yıllık dönemde, filmlerin dönemin toplumsal ve siyasal sorunlarını yankılayacak biçimde tematik vurgulara sahip olduğu görülmüştür. "Son erkek" motifinden başlayarak, nükleer felaket sonrası dünyadaki yaşam, zaman yolculukları, distopik dünyadaki çatışma, çöl savaşları, kaos ve zamanda alternatif akışlar yaratma gibi genel eğilimler gözlenmiştir.
\end{abstract}

Anahtar Kelimeler: Amerikan sineması, kıyamet ideolojisi, bilimkurgu, post-apokaliptik, ideoloji

Atıf: Boz, M. ve Takımcı, D. (2019). Amerikan Post-Apokaliptik Bilimkurgu Sinemasında Kıyamet İdeolojisi (1924-2000). Akdeniz Üniversitesi Iletișim Fakültesi Dergisi, Haziran (31), s. 377-403

\footnotetext{
1 Bu çalışma 2018 yılında tamamlanan "2000 Sonrası Amerikan Post-Apokaliptik Bilimkurgu Sinemasında Kıyamet İdeolojisi” başlığıyla E.Ü. S.B.E. sunulmuş Doktora Tezi'ne dayanarak hazırlanmıştır.

2 Dr. Öğr. Üyesi, Bozok Üniversitesi, İletişim Fakültesi, Radyo Televizyon ve Sinema Bölümü, bozmikail@gmail. com, ORCID Numarası: 0000-0003-4276-1521.

3 Sorumlu Yazar / Corresponding Author

4 Prof. Dr., Ege Üniversitesi, İletișim Fakültesi, Radyo Televizyon ve Sinema Bölümü, dilek.takimci@ege.edu. tr, ORCID Numarası: 0000-0001-7800-1685.
} 


\title{
Apocalyptic Ideology in American Post-Apocalyptic Science Fiction Cinema (1924-2000)
}

\begin{abstract}
This study focuses on how large-scale global fears for the forward future are represented in cinema, especially in pre-2000 American post-apocalyptic science fiction films. It targets to understand the changes and transformations of the ideologies represented and to show what kind of future imagination of apocalyptic ideology. In this framework, with historical and ideological perspective the post-apocalyptic science fiction films which are produced in the USA were revealed. After the introduction of premise films in the first half of the twentieth century in which the genre emerged, the films were examined at ten annual intervals after the World War II, when the genre films production has started to rise. The themes and motifs that stand out in these time periods have been researched by ideological film analysis method of L. Giannetti within the framework of the concept of apocalyptic ideology defined by Klaus Koch. In this way, the general characteristics and conventions of the genre have been described and illustrated by historically. As a result, it has been seen that in every decade, the films have thematic accents that echo the social and political problems of the period. Beginning with "the last man" motif, general trends such as life in the post-disaster world, time travels, conflicts in the dystopian world, desert wars, chaos and creating alternative flows in time were observed.
\end{abstract}

Keywords: Cinema, apocalypse, science fiction, post-apocalyptic, ideology

\section{Giriș}

çinde bulunduğumuz çağ insanlığın yepyeni bir döneme geçişinin arefesidir. Bilim ve teknolojide baş döndürücü ilerlemeler elde edilirken, birkaç nesil önce bilimkurgu görünen şeyler hızla gündelik yaşamda yer bulmaktadır. Dünya nüfusu yedi milyarı aşmış, kentler en büyük yerleşim alanı haline gelmiştir. Önceden aylar süren yolculuklar şimdi birkaç saatlik zamana sığarken, roket teknolojisi "keşifler çağı”nı uzaya taşımıştır. Atomun yapısının keşfedilmesi ile füzyon yoluyla enerji üretim biçimleri sınırsız bir enerji potansiyelini insanlara sunmaktadır. Bilgi ve iletişim teknolojileri hızla gelişmekte ve insanlar geçmişte olmadığı kadar daha hızla etkileşime girebilmektedir. Endüstriyel üretimde robot ve makinelerin artan kullanımı ve gelişmekte olan nanoteknoloji yepyeni bir üretim devriminin habercileridir. Geliştirilen mercekler, elektro manyetizma, radyo dalgaları gibi teknik gelişim ve keşifler makro ve mikro kozmosun oluşumu ve dönüşümü konusunda yeni bilgiler sağlamakta, geleneksel inançları dönüştürmektedir. Sağlıktaki gelişmeler insan ve diğer canlıların organizmalarını daha iyi tanıma imkânı sunmakta, insan ömrü düzenli bir şekilde artmaktadır. Bu ve buna benzer sebeplerle, yaşadığımız dönem "insan çağı" olarak da ifade edilmektedir. Antroposen kavramı, 
dünyanın jeolojisi ve ekosistemi üzerindeki artan insan etkisini ifade etmektedir ${ }^{5}$. Sonuç olarak insanlığın yaşadığı dünya üzerinde radikal bir değişiklik yarattığını söylemek mümkündür (Crutzen, 2002; Edwards, 2015).

İnsanlığın ve onun (şimdilik) yaşayabildiği tek gezegen olan dünyanın geleceğine yönelik endişelerde sürekli bir artış söz konusudur ve bu korkunun merkezinde yine insan unsuru bulunmaktadır. Korku yersiz değildir. İlk defa 1947 yılında Atom Bilimcileri Bülteni (BPA) tarafından oluşturulan ve "Kıyamet Saati" olarak bilinen, kıyameti sembolize eden "gece yarısı"a ne kadar zaman kaldığını gösteren saat, 25 Ocak 2018 tarihinde 30 saniye ileri alınmıştır. Böylece insanlığın yok olmasında sadece "2 dakika" kalmıştır. Bu sembolik saatin ileri alınmasında çeşitli nedenler bulunmaktadır. ABD Başkanı Donald Trump gibi siyasetçilerin eylemlerinin "öngörülemezliği", Kuzey Kore'nin nükleer denemeleri, ülkeler arasında artan kamplaşma ve çatışma, iklim değişikliği ile mücadele eden uluslararası kurumların etkisinin zayıflaması ve ABD'nin nükleer harcamalarını artırma stratejisi gibi nedenler bunlardan bazılarıdır (Chan, 2018). Bu sorunların yanı sıra küresel ısınma, yapay zekâ ve robot teknolojisinin getirdiği olası riskler, viral salgın, dünya dışı yaşam formlarıyla temas, su gibi stratejik kaynaklar üzerindeki uzlaşmazlıklar ve bölgesel ve genel savaş riski, geleceğe hakkındaki endişeleri sürekli arttırmaktadır.

Sinema sanatında, özellikle Hollywood film endüstrisinde kıyamete ilişkin korkular rağbet edilen konulardan biri olmuş ve bu alanda çeşitli tür kategorileri oluşmuştur. Sontag'ın (2015, s. 281) vurguladığı gibi, bilimkurgu filmleri sadece bilim hakkındaki filmler değildir, aynı zamanda "felaket" hakkındadır ve iyi bilimkurgu filmlerinin çekirdeği bu yıkımın imgeleminde yatar. Dolayısıyla bu imgelemin yapılandırılma biçimini anlamak ve bu temsillerin tarih içerisindeki dönüşümünü incelemek önem kazanmaktadır.

\section{Amaç, Yöntem ve Çalıșma Evreni}

$\mathrm{Bu}$ çalışmanın çıkış noktası yukarıda açıklanan kıyamet korkuları ve bu kıyamet korkularının sinema sanatındaki temsilleri ideolojik açıdan nasıl belirlediği sorunudur. Bu çerçevede ABD'de, bu ülke yapımcıları ya da ortaklığıyla üretilen post-apokaliptik bilimkurgu filmleri, tarihsel bir perspektifle, dönemlere ayrılarak, bu filmlerde öne çıkan tematik vurgu, motifler ve betimlenen dünyanın değişimi kıyamet ideolojisi kavramı çerçevesinde incelenmiş, niteliksel ideolojik film analizi yöntemiyle Amerikan postapokaliptik bilimkurgu sinemasının değişiminin izi sürülmüştür. Bu aşamada K. Koch'un kıyamet ideolojisinin unsurlarının varlığı ve yokluğuna ilişkin tasnifi filmlerde aranmıştır. Koch'a göre (Aktaran, Collins, 1998, s. 12). "tarihsel bir hareket olarak kıyametin ön gösterisi” sekiz motif kümesini içermektedir. Bu özellikler şu şekilde sıralanmaktadır:

1. yakın gelecekte dünyasal koşulların sona ermesi için acil beklenti;

2. kozmik bir felaket olarak son;

3. (tarihin) dönemselleştirilmesi ve determinizm; 
4. meleklerin ve iblislerin faaliyeti;

5. özgül biçimiyle cennetimsi olan yeni kurtuluş;

6. Tanrı'nın krallığının tezahürü;

7. ayrıcalıklı işlevleri olan bir arabulucu;

8. (iyiliğin) "zafer"i.

Bu kıyamet ideolojinin varlık ve yokluğu tasnifinden sonra da filmlerde öne çıkan ideolojik eğilimler L. Giannetti'nin (2008, s.454, 463) filmlerde belirli değer sistemi ve bunların hâkim ideolojilerle bağlantısını ortaya koymaya dönük ideolojik analiz yöntemi kullanılmıştır. Bu hâkim değerler düalist bir perspektifle; demokratik/hiyerarşik, çevre/ ırsiyet, göreceli/mutlak, seküler/dindar, gelecek/geçmiş, işbirliği/yarışmacı, dışarıdaki/ içerdeki, evrensel, milliyetçi, cinsel özgürlük/tekeşli evlilik olarak belirlenmiştir. Bu tasnif ve yöntem tüm filmlere tek tek raporlar hazırlanarak uygulanmış, genel olarak dönemdeki filmlerin genel ideolojik temaları ve toplumsal olguları sorunsallaştırmaları ortaya konmuştur.

Çalışma başlangıcından milenyal dönüşüme kadarki dönemde ABD'de yapılmış tüm post-apokaliptik bilimkurgu filmleri incelemektedir. İki büyük dünya savaşına sahne olan bu dönem, insanlıkta kitlesel ve büyük bir yok oluş korkularının en fazla yükselişe geçtiği dönemdir. İkinci Dünya Savaşı'nda ABD'nin Japonya'ya attığı atom bombaları, sonrasında siyasi çehredeki iki kutuplu bölünmüş Soğuk Savaş dünyası bu dönemin gelecek korkularını anlamayı önemli kılmaktadır. 1950’lerde bilimkurgu türünün yükselişe geçtiği "altın çağ" ile birlikte bu türde filmlerin sayısında bir artış olmuştur. Çalışmada 1950'lerden itibaren, tarihsel incelemelerde tarafsız ve tasnif amacı taşıyan bir yöntemle onar yıllık periyotlarla filmler incelenmiştir. Böylece her periyotta öne çıkan temalara ilişkin belirli nesnel tasniflere ulaşmak mümkün olmuştur. Soğuk Savaş'ın bittiği 1990'lar ile birlikte 2000 sonrasında savaş korkularında bir azalma söz konusu olmuştur. Bu dönemde küresel ısınma gibi korkular yükselişe geçmiştir ve yeni medya türlerinin ortaya çıktığı bir dönem olarak 2000 sonrası ayrı bir incelemeyi hak etmektedir.

Bu bağlamda Amerikan post-apokaliptik bilimkurgu filmlerinde ${ }^{6}$ kıyamet ideolojisini incelemeye yönelik bu çalışmanın kuramsal alt yapısını oluşturan apokaliptik, bilimkurgu, post-apokaliptik ve kıyamet ideolojisi kavramlarını açıklamak yol gösterici olacaktır.

6 Literatürde post-apokaliptik bilimkurgu filmlerine dönük sınıflandırma, tasnif ve hakim ideolojileri belirlemeye dönük çalışmalar sınırlıdır. Broderick'in (1993) Uzakdoğu, Avrupa ve Amerika'daki üretilmiş filmleri kataloglama çalışması, Grossman (2011), Bø (2013), Mishina'nın (2016) Yüksek Lisans ve Moon (2014) ve Harris'in (2016) Doktora tezleri dışında 2000 öncesi post-apokaliptik filmleri sınıflayan ve onlar hakkında bilgi veren çalışmalar bulunamamıştır. Bu yüzden bu çalışma 2000 öncesi dönemde bu türdeki filmleri hakkında ayrıntılı ve sistematik bir liste sunmakta, bu filmlerin tema, motif ve temsil ettiği ideolojik anlamları genel olarak ortaya koyarak literatürde önemli bir boşluğu doldurmaya çalışmaktadır. Post-apokaliptik filmler bilimkurgu türünün uylaşımlarını da taşıması nedeniyle bu türün bir alt türü olarak kabul edilmektedir. Bu alt türün kendine özgü çeşitli uylaşımları bulunmaktadır ve henüz literatürde bunlara ilişkin ayrıntılı bir tanımlama yapılmadığı görülmüştür. Bu çalışmada bu alt türe ait özelikler betimsel ve tümevarım yöntemiyle ortaya konmuştur. Bu yüzden sonuç kısmında ortaya konan özellikler de bu filmlere ilişkin daha derinlikli analizler için bir çıkış noktası olabilecektir. Çalışma bu yönüyle 2000 öncesi post-apokaliptik filmler için genel ancak sistematik bir görüş edinilmesinde literatüre önemli bir katkı sunmakta, hem de 2000 sonrası filmleri anlamaya ve onlarla öncesi dönemde çekilmiş filmleri karşılaştırma anlamında bir çıkış noktası sağlayacaktır. 


\section{Apokaliptik Vizyonlar, Bilimkurgu ve Post-Apokaliptik Tür}

\subsection{Apokalips ve Kıyamet İdeolojisi}

McGinn'e göre, apokalips, yani 'kıyamet' kavramı “ilahi bir sırrın açığa çıkarılması, "vahiy" anlamına gelmektedir; kehanet ve eskatoloji ile yakından ilişkilidir (1979, s. 1-3). Apokalips kavramının tanımı şu şekilde yapılmaktadır:

"Belli bir anlatıma dayalı, bir anlatı çerçevesine sahip olan bir tür, bir vahiy, başka dünyadan bir varlığın aracılığıyla bir insan alıcısı dünyevi varlığa aktarılan, eskatolojik kurtuluşu öngördüğü sürece hem zamansal hem de diğerini içerdiği ölçüde mekânsal olarak, doğaüstü gerçekliği ortaya koyan, bir aşkın gerçekliği ifşa eden, doğaüstü dünya» (Aktaran, Collins, 1998, s. 5).

Collins, apokalips kavramının bir edebi tür, apokaliptisizmin ise toplumsal bir ideoloji olarak kabul edildiğini belirtmektedir. Apocalypticism yani kıyametçi ideoloji ve apokalipste merkezi önem insan hayatının doğaüstü bir dünyanın melekleri ve şeytanları tarafından çevrelendiği ve gelecekte kaçınılmaz bir son yargının olacağı düşüncesine verilmektedir. Bu aynı zamanda toplumdaki önemli problemlere dair bakış açısı sunmaktadır. Kıyamet toplumsal ve tarihsel durumlardan türetilmiş bir düşüncedir. Şimdiki zamandan kopma, ona yabancılaşma, özellikle tarihsel olanında olmak üzere, pek çok apokalipste temel önemdedir. Apokalips, eskatolojinin merkezi bir noktasında bulunmaktadır (Collins, 1998, s. 2-24). Kermode'e göre (2000, s. 8, 94), kıyamet düşüncesi hayal edilmiş kaydedilmiş bir geçmiş ve hayali olarak tahmin edilen bir gelecek arasındaki uyuma dayanmakta, insanlar ise bunun ortasında bulunmaktadır. Artık "Zaman özgür değildir, o mitik bir sonun kölesi" haline gelmektedir.

Apokaliptik kıyamet mitleri, tarihin veya dünyanın sonunu anlatan eskatolojik mitlerdir. Werblowsky, eskatoloji kavramının "son şeylere ilişkin" bilim ve öğretiler anlamına geldiğini belirtmektedir. Yunanca son anlamına gelen "eschatos" veya son şeyler anlamına gelen "eschata"dan türetilen eskatoloji bireysel ve kozmik/genel biçiminde ayrıma tabii tutulmaktadır. Bireysel eskatoloji kişinin ölümünden sonraki kaderi, mistik durumu, yargılanması ile ilgili iken, kozmik eskatoloji şimdiki dünyanın dönüşüm geçirmesi, onarılması ya da tümden yok olması anlamına gelmektedir. Bununla birlikte eskatoloji mutlak bir "sona" atıf yapmamaktadır; "yeni cennet ya da yeni dünya" olarak ifade edilebilecek bir dönemlere gönderme yapmaktadır (2005, s. 2383-2384). Bu bakımdan son, daha özgül biçimde "yeni bir başlangıç için" sondur.

Yeni bir başlangıç ya da ütopik geleceğin doğuşu fikri sonradan kıyamet ve Mesih fikirleriyle birleşmiştir. Bu durum ya bir kral ya da kutsal bir figür aracılığıyla görkemli bir ulusal restorasyonun mümkün olduğu/olacağı fikirlerine yol açmıştır. Bu türün daha çağdaş örneklerinde ise vurgu noktası kozmik bir felaket beklentisi ve kurulu dünya düzeninin yakın zamanda değişeceğine dönük inançlar olarak varlıklarını sürdürmektedir (Werblowsky, 2005, s. 2384-2386; Collins, 2005, s, 409-414).

Cevizci (1999, s. 697), "post" kavramının "den sonra" anlamına gelen Latince bir ön ek olduğunu belirtmektedir. Bu ek, "bir durumu, yapıyı veya oluşumu, ikinci olarak da bir 
akımı, yaklaşımı tanımlayan bir sözcüğün önüne gelebilmektedir”. Her iki biçimde de eski yapıdan veya önceki akımlardan unsurlar içerilse de büyük ölçüde yeni ve farklı bir oluşum ya da yaklaşım ifade edilmekte, ona gönderme yapılmaktadır. Bu bağlamda post-apokaliptik, yaşanmış bir büyük felaketin ya da kıyametin sonrasıyla, sonraki durumla, bu yaşamla ilgili olmakta, bu durumu belirtmektedir (Post-apocalyptic, 2017). Bilimkurgunun alt türü olarak post-apokaliptik terimine ilk referans The Magazine of Fantasy and Science Fiction dergisinin 1970'teki sayısında yapılmıştır (Harris, 2016, s. 30). Post-apokaliptik kurgu, dünya üzerinde kurulu olan yaşamın büyük ölçüde sonu geldiğinde insanların yeni bir başlangıcı nasıl oluşturacağını ele almaktadır. $\mathrm{Bu}$ kurgular bilimin ve teknolojinin, elektriğin yokluğu yanında rastgelelik, kontrol edilemezlik, neslin bitimi, ölüm gibi unsurlarla ilgilidir. Bu kurgu, "ne olur" (what if?) sorusu üzerine yoğunlaşmaktadır ve bilimkurgu, korku ve ütopya/distopyanın geçiş noktasında bulunmaktadır (Curtis, 2010, s. 5, 7). Seed'e göre "Felaket, kıyamet ve dünyanın sonu, hepsi kökleri antikitede olan temel bilimkurgu temaları olmuştur" (2011, s. 113). Bu durum çağdaş toplumsal, siyasi yaşam ve teknolojideki kimi gelişmelerde doğrudan etkileşim halindedir. Post-apokaliptik ve apokaliptik hikâyelere dönük ilgi, Moon'un (2014, s. 240) vurguladığı gibi genel bir sona ilişkin ilginin yanında özel tarihsel durumlarla ilgilidir. 1929'daki Büyük Depresyon, ABD'nin Vietnam yenilgisi ya da 11 Eylül 2001 Saldırıları bu tarihsel olaylardan bazılarıdır. Bu yüzden özellikle İkinci Dünya Savaşı'ndan sonra bu türde film ve eserlerin artışında toplumsal yaşamdaki gerilimlerin büyük bir etkisi bulunmaktadır. Buckland'a (2002, s. 98) göre geçen yüzyıl itibariyle, tarih boyunca ilk defa insan kendi kendisini yok edecek bir teknolojik ve bilimsel gelişmeye erişmiştir. Böylece insanlık yok edilmeye karşı dayanıksızdır. Yabancı bir yaratık tarafından istila gibi konuları genellikle Soğuk Savaş döneminde komünistlere dönük temsiller yoluyla dışsallaştırma söz konusudur. Bu açıdan yıkım düşüncesi ve istencinin tarihsel bir süreklilik olarak ortaya çıktığını söylemek mümkündür.

\section{Bilimkurgu Sinemasında Post-Apokaliptik Tür}

Bilimkurgu alanında ilk kez Hugo Gernsback (1884-1967), 1908 yılında Modern Electirics adlı dergiden başlayarak "bilimin harikaları" ve sonrasında kurduğu dergilerde olağanüstü konuları işleyen metinleri bir araya toplamıştır. 1926 yılında çıkarmaya başladığı Amazing Stories dergisi ise ABD'de sadece bilimkurgu eserlerine ayrılan ilk "ucuz dergi"dir (pulp magazine) (Baudou, 2005, s. 7-8, 32). Gernsback (1929, s. 5), "bilimkurgu" (science fiction) terimini ilk kez, Science Wonder Stories dergisinin ilk sayısına yazdığı sunuşta kullanmıştır. Gernsback bu dergide yalnızca temelini bilimsel yasalara ve bu bilimsel yasalara dayanarak yapılan mantıksal çıkarımlı öyküleri yayınlayacağını bildirmektedir.

Gernsback'ın tanımı, türe ilişkin tek tanım değildir. Roger Schlobin (1981) bilimkurgu ve fantazi üzerine altmış yedi yazarın tanımlarını listelemektedir. Bu tanımlamalar türe ilişkin tarihsel bir perspektif kazandırmaktadır. Türün doğasının sürekli yenilendiğini ve oluşturulduğunu, dolayısıyla tanımların da değiştiğini göstermektedir.

Roberts'e (2006, s. 1-2, 9, 17) göre bilimkurgu türünde "ne olur" (what if) oyunu 
önemlidir, vurgu noktası "gerçek" değil, bilimsel yöntem, belirli bir öncülün mantıksal işleyişi, farklı olan ile karşılaşmanın merkezi bir yoludur. Literatürde önemli bir etkisi olan Darko Suvin'in bilimkurgu anlayışı ise Bertolt Brecht'ten etkilenmiştir (Telotte, 2004, s. 4). Ona göre bilimkurgu bilişsel yabancılaştırma edebiyatıdır. Bilimkurgu kurgusal bir hipotezi alıp bilimsel bir düşünce ile birleştirme, tümleştirme çabasıdır. O meta-ampirik bir türdür ama metafizik değildir. Suvin (1979, s. vii, 4-8, 18, 20) bilimkurgunun tanımını "yeterli ve gerekli koşulları, bilişselliğin ve yabancılaştırmanın varlığı ve etkileşimi, ana biçimsel aygıtı yazarın ampirik çevresine alternatif yaratıcı bir çerçeve olan edebi bir tür" olarak belirtmektedir. Yabancılaştırma, bir nesnenin alışık olmayan biçimde gösterilmesi, yabancılaştırıcı kurgu ise, toplumsal ve çevresel ilişkileri, tümüyle ya da önemli ölçüde yaşanılan zaman-yer ilişkisinden farkılıştıran, genel ortak duyuya hitap etmeyen bir kurgu, bir özellik olarak sunulmasıdır. Bilişsel edebiyatın natüralistik olanı realist, yabancılaştırma özelliği olanı bilimkurgudur. Yabancılaştırma edebiyatının bilişsel olmayanı ise metafiziktir, mit, masal ve fantezidir. Oskay (2014, s. 30-35), Suvin'in bilimkurgu anlayışının ütopik ve distopik bilimkurgu ürünlerini sadece iyi ve kötü olarak sayılması anlamına gelmeyeceğini, her bilimkurgu eserinin canonic değil, diachronic olduğu dolayısıyla bu iki öğenin yüksek ve düşük düzeydeki bilimkurgu eserlerinde birlikte bulunabileceğini söylemektedir; bu yüzden başat noktaya bakılmalıdır. Oskay, Suvin için bilimkurgunun yeni olanın (novum) keşfedilmesinde bir araç (organon) olduğunu düşünmektedir. Yaşanan dünyanın alışıımış algılanmasına karşı olan bilimkurgu bu yönden yabancılaştırıcı bir etki üreterek yeni olana, "vadi paradigması" ile kişinin kendi nesnel dünyasından başka, öteki dünyaların da olabileceğini göstermektedir.

Post-apokaliptik kurguda, kıyamet gerçekleşmekte olan bir süreç değildir. Tarihsel olarak gerçekleşmiştir ve artık kıyametin etkilerinin varlığı söz konusudur. Bir açıdan kıyamet öncesinin insanı, mitik 'olgunlaşmamış' insandır. Çünkü halen çocukluk döneminde olan insanlık, kendi varlığını tümden yok ederek, aslında erginleşme için gerekli olan fiziksel ve ruhsal dönüşümü sağlamış olacaktır. Bu bakımdan post-apokaliptik kurgu yıkımı zorunluluk olarak gördüğü kadar onu araçsallaştırıp yeni bir başlangıcı da önvarsayım olarak kabul etmektedir. Roloff ve SeeBlen'e (1995, s. 100) göre kıyamet teması "dünyada gereksiz ve fazla olanı da bir temizleme" sürecidir ve böylece her şey yeni baştan başlayabilecektir. Broderick'e göre, uzak bir dönemde, yıkım sonrası dünyaya ilişkin yansıtmalar, yıkım gerçekleştiği ana ilişkin sahneleri atlamaktadırlar ve böylece izleyici nükleer felakete yönelik insan etkisini gözden kaçırmaktadır. Yanı sıra bu filmlerin bir kısmı, bu zamandaki yaşamı ideolojik bir tartışmanın konusu yapmaktadır. Diğer filmler ise yüksek düzeyde gerici bir tavır sergilemekte, muhafazakâr toplumsal rejimin ataerkil yasaları ve bunlara hayranlık yoluyla statükonun sembolik yasalarının avukatığını yapmaktadırlar. Bu filmler yıkımı kutlamasalar bile, yıkımı (post)modern yaşamın baskıcı unsurlarını ortadan kaldırıp, daha az karmaşık tarımsal varoluşlara ve toplumsal uyuma yönelik nostaljik bir özlemi dile getirmektedirler (1993, s. 362). Postapokaliptik hikâyeler, mevcut düzenin ortadan kaldırılması düşüncesiyle ilgilidirler. Böylece bir tersine çevrinme yaşanmaktadır. Uygarlığın kontrolü altındaki bir doğadan doğanın kontrolü altındaki insanlığa geçiş söz konusu olmaktadır (Moon, 2014, s. 5-6). Sontag'a (2015, s. 281, 284, 296) göre bilimkurgu düşünülemez ve felaketle ilgili 
olmasının sebebi insanın dehşet ve korku duygularına yönelik tepkilerinin yetersizliğidir. Yıkım gerçekleşirken görünen "güzellikler", bilimkurguyu yıkımın estetiği hakkında bir tür yapmakta, bu yolla aynı zamanda ahlaki bir basitleştirme yapılmaktadır. Böylece, normalde zalimce görünebilecek ya da ahlaksızca hislere tercüman olabilecek fanteziler ahlaki bakımdan kabul edilebilir hale gelmektedir. Bu yaklaşım ile bağıntılı olarak post-apokaliptik filmler ele alındığında, gizemli bir virüs, deprem, uzaylı istilası, doğa verimsizliği, küresel ısınma vb. bir gerekçeyle insanlığın büyük bir kısmının, örneğin yüzde \%99'unun, ortadan kalktığı düşünesi, insanlığı ya da canlılığı belirli bir sayı ya da orana indirgemektedir.

Şimdiye kadar kuramsal çerçevesi çizilen bilgiler gözetildiğinde, post-apokaliptik bilimkurgu filmlerini, korku türüyle etkileşim içinde, bilimkurgu sinemasının tematik bir alt türü olarak kabul etmek mümkündür. Post-apokaliptik filmler, yabancılaştırıcı etkilerini, izleyicinin şimdiki zamanından radikal olarak farklı bir dünya/mekân tasarımı yaparak ortaya koymaktadırlar. Bu filmler, yıkımı, sıklıkla dışsal bir sebebe dayandırsalar da bu sebebin kökeninde insanın teknolojiyle kurduğu ilişkinin niteliği yatmaktadır; dünyaya ve yaşama ilişkin bakışın rasyonel niteliği merkezi bir sorun olarak kavranmaktadır. Bu filmleri yakın ya da uzak geleceği şimdiden tasarlayarak bu olası etkileriyle geleceğe ve insan etkinliklerine, bunların olası sebeplerine ilişkin bilişsel bir ortam hazırlamaktadırlar. Onlardaki özgül novum, yeni, şimdiki zamandan radikal olarak farklı tasarımlanmış mekân ve zamanın kavranışıdır. Sobchack'ın belirttiği gibi bilimkurgunun özgül yanı toplumsal düzenin bozulması (2001, s. 30) fikridir. Bu filmlerdeki karakterler, ikonografi, zamanın kavranışı, teknolojik aletlerle ilişki ise, türün uylaşımlarını yeniden yorumlayan, kendine özgü bir çerçeveye sahiptir. Özden'in (2004, s. 277) vurguladığı gibi tür filmleri incelenirken, türe ait külliyatın bilinmesi, anlatım geleneklerinin ve temel karakterlerin tanınması, filmin kültürel bir bağlama oturtulması gerekmektedir. Bu bakımdan türün erken dönem örneklerinden yola çıkarak ve özellikle İkinci Dünya Savaşı sonrasındaki yaklaşık yarım asırık dönemi on yıllık dönemlere bölerek yapılacak genel bir inceleme post-apokaliptik Amerikan bilimkurgu sinemasının 2000 öncesindeki özgül yönlerini görmek açısından önemli bir çerçeve sağlayacaktır.

\section{2000 Yılına Kadar Post-Apokaliptik Bilimkurgu Sinemasının Dönüșümü}

Geraghty (2009, s.2-4), bilimkurgu türünü "derin biçimde Amerikan türü" olarak nitelendirmekte, bilimkurgunun çağdaş Amerikan toplumunu metaforlar yoluyla yansıttığını belirtmektedir. Amerika mitik bir diyar olarak kavranmaktadır. Zira oradaki kimi gruplar için burası ideal cennetlerinin gerçekleşeceği vaat edilmiş diyar olarak düşlenmiştir. Harris (2016, s. 14, 20, 30) ise, post-apokaliptik kurguların başarısızlık ve yıkım yanında hayatta kalma, yeniden doğma ve yenilenmeyi görselleştirdiğini, bu temanın Püriten ahlakını da kapsayacak biçimde Amerikan ulusal kimliğinin bir parçası olduğunu belirtmektedir. Amerika'nın kendisi de post-apokaliptik bir diyardır. Zira, Amerika'ya ilk ulaşan beyazların ardından pek çok yerli hastalıklarla ve katliamlarla ölmüştür. Tüm bu yıkımların ardından bölgede ABD kurulmuştur. Bu bağlamda post- 
apokaliptik tema geleceğe dair bir görüş sunsa da "mitolojikleştirilmiş bir Amerikan geçmişinin yeniden yaratımıdır". Bu açıdan post-apokaliptik bilimkurgu filmlerinin Amerikan toplumsal yaşamında önemli bir yeri olduğunu söylemek mümkündür. Dolayısıyla Amerikan sinemasında sürekli bu temanın kendine yer buluşunun geleceği imgelemek yanında geçmişi yeniden diriltme çabasının izlerini görmek olasıdır.

\subsection{0’ye Kadar Illk Örnekler: Dünyanın “Son” Erkekleri}

ABD'de türe ait ilk örnekler ${ }^{7}$ komedi-bilimkurgu karışımıdır. Türe ait ilk örnek, John G. Blystone'un 1924 tarihli The Last Man On Earth'tür. Filmde (filmin çekildiği tarihe göre) gelecekte, 1940'ta, bir adam âşık olduğu bir kız tarafından reddedilip aşağılanır ve adam ormanda inzivaya çekilir. 1950 yılında ise sadece erkekleri etkileyen "masculitis" virüsü erkek nüfusunu yok eder ve bu kız tarafından reddedilen adam bir ulusal hazine değeri kazanır. Aynı tema, ikinci film olan It's Great to be Alive (Alfred L. Werker, 1933) filminde de tekrarlanmaktadır; gizemli bir virüs, ölen erkek nüfus ve virüsün yayılmasından önce Güney Pasifik'te bir adaya çarpan pilot ve pilotun döndüğünde dünyadaki son erkek olduğunu anlaması söz konusudur. Deluge (Felix E. Feist, 1933), dramatik öğelerin de bulunduğu, yıkımı doğal bir görüngü olarak sunan bir filmdir. Filmde dünyadaki hava durumu hızla değişmekte, basınç, rüzgâr hızı gibi etkenler bilinen dünyanın hızla değiştiğini göstermektedir ve New York şehri özelinde gösterilen deprem, uygarlığın en büyük başarılarını, gökdelenleri, binaları, Özgürlük Anıtı>nı, yıkmaktadır ve ardından gelen dev okyanus dalgaları dünyanın önemli bir kısmını sular altında bırakmaktadır. Deluge etkileyici bir şekilde kıyameti görselleştirmektedir. Broderick erken dönem felaket filmlerinin, zamanın küresel krizlerinin görünümleri olan Dünya Savaşı, 1917 Sovyet Devrimi, Büyük Buhran gibi olguların korkularını yansıttığını düşünmektedir (1993, s. 364). Sonuç olarak henüz tehlike dışsal ve kontrol edilemez düzeydedir. İnsanlık bu aşamada kendi şanssız yazgısıyla yüzleşen bir tür olarak görülmektedir.

\subsection{Bilimkurgunun “Altın Çağı”": 1950’lerde Nükleer Savaș Sonrası Dünya}

Bilimkurgu sineması ancak 1950'den sonra bir tür olarak ortaya çıkmıştır (Sobchack, 2001, s. 12; 2005, s. 261). 1950'ler, post-apokaliptik filmlerin hem bağımsız hem de büyük yapım şirketlerince üretildiği bir dönem olmuştur. Bu dönemde üretilen filmlerin üç tanesi, Captive Women (Stuart Gilmore, 1952), World Without End (Edward Bernds, 1956) ve Teeange Cave Man (Roger Corman, 1958), savaşın bitmesinden çok sonraki yaşamı ele alırken, Five (Arch Oboler, 1951), Robot Monster (Phil Tucker, 1953), Day the World Ended (Roger Corman, 1955), The World, the Flesh, and the Devil (Ranald MacDougall, 1959) ve On the Beach (Stanley Kramer, 1959) savaşın etkilerinin henüz sürmekte olduğu dönemi konu edinmektedir. Filmlerde yalnızca Robot Monster felaketin nedenin uzaylı istilası olarak görse de bu istiladan dolayı kafası karışan dünya devletlerinin nükleer silaha sarıldığını ifade etmektedir. Dolayısıyla bu dönemdeki

7 Post-apokaliptik sinemanın ilk örneği Danimarkalı yönetmen August Blom'un Dünyanın Sonu (Verdens Undergang, 1916) adlı eseridir. 
filmlerin, nükleer bombaların insanlığı tümüyle yok edecek olası etkileri konusunda tepkileri yansıttığını söylemek mümkündür.

Five, teknolojik gelişmelere karşı muhafazakâr değerlerin ön plana çıktığı, bilime ve insanlığın sınır tanımaz biçimde dünyayı fethetmesine dönük çabalara karşı kuşkulu, yok oluşu dışsal bir şey olarak görse de 'malumun ilanı' olan bir 'gereklilik' olarak görmektedir. Film yıkım sonucunda kurulacak toplumsal yapının ancak çalışkanlık, mütevazılık, dışarıya karşı kuşkulu, bu yeni toplumsal duruma karşı 'tam hazır' olmayanların bir şekilde ortadan kalktığı tekçi bir dünya tasavvuruna sahiptir. Captive Women, merkezine New York kentini ve bu kent için mücadele eden üç grubu almaktadır ve eski dünyanın kalıntılarını ya da insanların kendisini yeni bir mücadele alanı olarak ortaya koymaktadır. Robot Monster, nükleer silahlara dönük bir ilgi gösterse de bu ilgiyi bu silahların olası tehlikeleri bağlamında tartışmamaktadır. İnsanlık için acil görev Ro-Man istilasına yol açacak ya da onu engelleyecek daha güçlü bir silahın geliştirilememesidir. Day The World Ended, nükleer silahların tehlikesine dikkat çekmektedir ve bunun sadece doğayı dönüştürmekle kalmayıp insanı da kötü hale getirdiğini, bunun doğal ve tanrısal yasaların ihlali olduğunu ortaya koymaktadır. Nükleer felaket ve radyoaktif kirlenme insanı dönüştürmekte, onu çiğ et yemeye ve yamyamlığa eğilimli hale getirmektedir. Captive Women'da olduğu gibi mutasyona uğramış yaratıklara dönük öteki algısı belirmeye başlar. Film yeni durumu yeni bir başlangıç için araç olarak görür ve daha geleneksel ilişkilerin hâkim olduğu bir toplumu ideal bir yapı olarak ortaya koyar. World Without End, nükleer silahların tehlikesine dikkat çeker ve bunun sadece doğayı dönüştürmekle kalmayıp insanın bir kısmını kötü, canavar ya da yeraltına çekildiğinde 'kadınsı' yaptığını ortaya koyar. Nükleer felaket ve radyoaktif kirlenme insanı dönüştürürken yapılması gereken, geçmişten gelen bir grup insanın, yeni dünyanın yeraltı sakinlerine, cesareti, gücü, özgeciliği göstermesidir. Böylece şiddetin yeniden kullanılması, mutasyona uğrayanların toptan sürgünü, şiddet uygulayan erkeklerin yeryüzünü fethe çıkması gibi süreçlerle gelecek dünyasında, geleceğin bir kısım bilgeliği (çünkü silahlar sadece küçük amaçlar için kullanılır) ile geçmişin silahlı gücü arasında bir denge kurulmaktadır. Böylece mitik Amerika yeniden diriltilmeye çalışılmaktadır. Teenage Cave Man, insanlığın tarihsel gelişimini bazı nesnel süreçlerden kopararak, onu tarih dışı ele alarak ortaya koyar. İnsanlığın tarihsel gelişimi döngüseldir. Atomik uygarlık sürekli felaketle kendi varlığını sona erdirir ve ilkelliğe dönmektedir. Film gerçek toplumsal ve maddi ilişkileri anlamaya çalışmaz. Yenilik istenci olarak öne çıkan arayış miti, gerçeklerin bulunmasına yol açsa da film bunların bir farklılık getireceği konusunda yıkıma yenilik atfetmez. The World, The Flesh and The Devil filminde, Five'da olduğu gibi siyah ırktan insanlara sadece görünmekle kalmaz, aynı zamanda başkarakterdir. Film yıkım sonrası dünyada en önemli çatışma konusu olarak ırk ayrımcılığını görür ve beyaz bir kadın ile siyah erkek arasındaki eşitliğe dayalı aşk ilişkisini bir olasılık ve kadın tarafından arzulanan bir ilişki olarak ortaya koyar. Başka bir beyaz erkeğin varlığını göstermesi ise karakterler arasında bir çatışma yaratsa da sonucu değiştirmez. Film eski yıkıcı savaşlara, iki erkek arasında bir kadın için gerçekleşecek "Dördüncü Dünya Savaşı"na karşı tavır alır. Hayatta kalan kişiler için tek çözümün birliktelik olduğu, başlangıcın ancak böyle mümkün olduğunu gösterir. Son olarak On the Beach, nükleer savaşın sürmekte 
olan etkilerini, ölümü bekleyen bir grup şehir insanı ve askerler yoluyla ortaya koyar. Yıkıp yok etme güdüsünün insana içsel, dolayısıyla bu güdünün değiştirilmesinin zor olduğunu savlar. Suç yöneticilerin eline ölümcül bir oyuncak vermiş olan bilim insanlarındadır ve her zaman bir hata yapanın çıkacağı vurgusu filme hâkimdir. Film, bu savaştan kaçınmak için "hala zaman var" mesajı vermekle birlikte, nostaljik biçimde şimdiyi idealleştirip onun bir mutluluk, sorunsuzluk anı olarak sabitlemek istemektedir.

\subsection{0’lar: Zaman Engelinin Ötesindeki Yıkım}

1960 'larda çekilen post-apokaliptik filmler, felaket nedeni konusunda halen nükleer savaşı ve atomik gücün getirdiği tehlikeleri baş sebep saymakla birlikte, gizemli, kozmik, temelde sınıfsal, ırksalçatışmaları dile getiren ya da insan-maymun savaşı gibi yeni tematik unsurları da konu edinmektedir. Bu döneme hâkim olan eğilim, felaketin bir olasılık olarak gözlemlenmesine olanak tanıyan zaman yolculuğudur. Filmlerdeki geleceğe ilişkin uyarıcı ton azalmaya başlamaktadır ve yıkım, muhafazakâr ya da daha özgürlükçü bir toplumun inşasında bir araç olarak sunulmaktadır.

Last Woman on Earth (Roger Corman, 1960), filminde yıkım, tehlikeye düşen toplumsal düzen olarak anlam kazanır. Film felaket aracılığıyla aile ve para gibi unsurların anlamını yitirişi karşısında, bunları koruyucu muhafazakâr bir savunuya girişir. Beyond the Time Barrier (Edgar G. Ulmer, 1960), yıkımın sebebini uzaydan gelen kozmik radyasyona bağlayarak, felaketi dışsallaştırır; nükleer korkudan daha öte tehlikelerin mevcut olduğunu söyler. Nükleer denemeler atmosferin koruyucu tabakasını inceltmiştir ve dünyayı tehlikelere açık hale getirmiştir. Eser yoğun biçimde ötekilere, dışarıdaki olanlara karşı korkuları besler; Markova adlı zaman yolcusunun bir kargaşayı başlatması gibi, bu endişelerin haksız olmadığını ileri sürer ve tarihin alternatif seyri konusunda olasılıkları gösterir. G. H. Wells'in 1895 tarihli aynı adlı eserinden uyarlanan The Time Machine (George Pal, 1960), yapıldığı dönemden daha geçmişe gidip, birinci ve ikinci dünya savaşlarının etkisine dikkati çekerek, yakın gelecekte bir başka savaşın mümkün olduğuna ilişkin bir çerçeve sunar. Yeraltında ve üstünde yaşayan iki insan grubu sınıfsal bölünmelere gönderme yapar ve film, bu sorunların düzeltilmesi için modernist-aydınlamacı geleneğe dayanarak, bilimin yönlendirmesine gerek olduğunu, ütopik bir dünyanın kurulma koşullarının bunlar olduğunu öne sürer. Panic in the Year Zero! (Ray Milland, 1962), post-apokaliptik filmler içinde gerçekleşen yıkıma karşı en duyarsız biçimde yaklaşan, bunu muhafazakâr bir toplumun kuruluşu için araçsallaştıran ilk filmdir. Film gerçekleşen yıkımın hızlı sonuçlarının görüldüğü dünyayı resmeder. Bu bağlamda yapılması gereken en iyi şeyin hemen yiyecek depolayarak, toplumdan uzak durup, hatta onlarla tüm bağlantıları kopararak, çekirdek aileyi tehdit eden her şeyin ortadan kaldırılmasını sağlamak olduğunu iddia eder. Film geleceğe karşı ütopik bir tavır alıyormuş görünse de temelde tasarımlanan gelecek muhafazakâr, beyaz, orta sınıf Amerikanların temsil edildiği, milenyarist, 'iyilerin' yaşadığı bir dünyadır. The Creation of the Humanoids (Wesley Barry, 1962), filmi insanlığın büyük bir kısmının yok oluşunu nükleer bir felakete dayandırır. İnsanlığın giderek kısırlaşmasını, didaktik biçimde de olsa, insan ve makine arasındaki yeni bir 
ilişkiyi yeni bir "sürüm 2" insanın tartışılmasına araç olarak görmektedir. Bu bağlamda insan benliğini tartışmaya açmaktadır. Irkçı insan örgütlenmelerinin robotlara karşı saldırıları, güncel ırk ayrımcılığı sorunlarına bir göndermedir. Film "öteki”yi bir zararlıdan çok insanın yeni, hastalıksız, ölümsüz sınırlara doğru açılabildiği bir olanak olarak gören özgürlükçü bir vizyona sahiptir. The Last Man on Earth (Ubaldo Ragona, Sidney Salkow, 1964) daha sonra pek çok uyarlaması çekilen Richard Matteson'ın 1954 yılında yayınlanan I am Legend adlı romanının uyarlamasıdır ve yıkımı insanları vampire benzer yaratıklara çeviren bir virüse dayandırır. Kahraman, bir bilim insanı olarak sürekli hastalığa bir tedavi bulmaya çalışır, ancak tam da tedaviyi bulduğunda hastalar bu tedaviyi kabul etmezler. Hastaların hepsi siyah elbiselidir, hiyerarşik bir toplum düzeni içindedir. Hastalar aynı zamanda kendileriyle yüzleşemez ve yeniçağın süreksiz ilişkilerine karşı güvensizdir. Bu bağlamda hastalar G. Romero'nun zombi filmlerindeki alışveriş merkezlerinde avare biçimde dolaşan, tüketim toplumu üyelerinin öncülleri gibidir. The Time Travelers (Ib Melchior, 1964), nükleer felaketi ve yüzey/yer altı ayrışmasını geleceğin bir çatışma alanı olarak gösterir. Yıkım insanlık için yepyeni bir endüstriyel toplumu inşa etmek için araç olur ve insan başka yıldız sistemlerine gözünü dikse de mutasyona uğramış gericilerin saldırısı karşısında başarısız olur. Kahramanlar zamanı telafi etmek için sürekli uğraşırlar ve dünyanın kurtuluşu bir yönüyle dünyanın insandan kurtuluşu ile mümkün görünür. Dönemin blockbuster olarak öne çıkan yapımı Planet of the Apes (Franklin J. Schaffner, 1968) insanı zamansal çizgide farklı bir mekâna götürmekle kalmaz, bu radikal olarak farklı mekânı insanlık tarihinin içine yerleştirir. Film geleceğin dünyasında olumsuz bir maymun ve insan ilişkisi resmeder. İnsanlar avcı toplayıcı bir topluma gerilemiş, dil yeteneklerini yitirmiş, örgütlü bir toplum kurma becerileri kalmamıştır. Bu duruma gelerek, yani bilinçlerini kaybederek, günah işleme becerilerini de yitirmiş naif, kırılgan yaratık olarak kalmışlardır. Buna karşın maymunlar sıkı bir şekilde düzenlenmiş kast sistemleri, insanlara karşı barbarlıkları, maymun merkezli mantık ve ahlak anlayışları, tabularla örülmüş toplumsal organizmaları ile insanlığın şimdiki durumunu yansıtan bir çerçeve içinde resmedilir. Filmde maymunlarda temsil edilen kötülükler modern insana ait kötülüklerdir ve yaşamın anlamsızlığı, insanı farklı olanı aramaya iterken, bu farklı olan bile insanlığın bencilliği, yıkıcılığı, insan merkezli kavrayışının en 'iyi' ihtimalle tersine dönmüş bir yansısı olarak ortaya çıkmaktadır. Maymunların distopik olan dünyasına dönük her eleştiri radikal biçimde yeniden insana doğru döner; düşünümseldir. Film bu yansıtmayı etkin bir şekilde kullanır ve insanın distopya yaratma eğilimini sorgular.

\subsection{0’ler: Yıkım Sonrasının Distopyaları}

1970'lerde post-apokaliptik bilimkurgu filmlerinde kendini gösteren özgül yönlerden birisi gişe başarısı sağlayan blockbuster filmlerin daha fazla çekilmeye başlanmasıdır. Dönem boyunca Planet of the Apes'in iki tanesi, Beneath of te Planet of the Apes (Ted Post, 1970) ve Battle for the Planet of the Apes (J. Lee Thompson, 1973), postapokaliptik dönemi ele almak üzere dört devam filmi çekilmiştir. The Omega Man (Boris Sagal, 1971), Silent Running (Douglas Trumbull, 1972), Logan's Run (Michael Anderson, 1976) ve Buck Rogers in the 25th Century (Daniel Haller, 1979) gişede iyi 
gelir sağlayan diğer filmlerdir. Kendini gösteren bir diğer özellik, yıkım sonrası dünyada yeniden kurumsallaşan toplumsal ilişkilerdeki artan distopik vurgudur. Planet of the Apes, Silent Running, Logan's Run, Z.P.G. (Michael Campus, 1972), Idaho Transfer (Peter Fonda, 1973), Zardoz (John Boorman, 1974), A Boy and His Dog (L. Q. Jones, 1975), The Ultimate Warrior (Robert Clouse, 1975), Deathsport (Allan Arkush, Nicholas Niciphor, Roger Cormans, 1978), Ravagers (Richard Compton, 1979), Quintet (Robert Altman, 1979) gerçekleşen toplumsal gerilimleri çözmek ve rahatlatıcı olmaktan ziyade, ağırlıkla insanın doğasına yapılan bir kötülük atfıyla kendini gösteren baskıcı, otokrat toplumsal örgütlenmeleri serimlemektedir. Son özgül yön ise yarının dünyasının gençlere ait olduğu temasını içeren, merkezinde gençlerin bulunduğu filmlerin ortaya çıkışıdır. Gas-s-s-s (Roger Corman, 1970), hippi, karşı kültüründen etkilenerek çekilen, yirmi beş yaşın üzerindeki herkesin gizemli bir gazla öldüğü post-apokaliptik dünyayı, her şeyin serbest olduğu parodi bir dünya olarak resmetmektedir. Glen and Randa (Jim McBridge, 1971), yıkım sonrası dünyada genç bir erkek ve kadının buldukları bir çizgi romanla eski dünyanın şehirlerinden birini bulma yolculuklarını, eskinin natüralist ve yeni bir gözle keşfi olarak sunmaktadır. Idaho Transfer yaklaşan yıkımın etkilerinden kurtulup zaman yolculuğunun yıkıcı etkilerinden zarar almadan kurtulan gençler vasıtasıyla sorunları yıkımın doğrudan etkilerini atlayarak çözmeye çalışmaktadır. Ancak genelde başarısızlığa uğrayan proje, sonunda geçmişten gelen insanların gelecektekiler tarafından yakıt olarak kullanıldığı, distopik, karamsar bir havayla son bulur. A Boy and His Dog, telepatik bir köpekle genç bir çocuk arasındaki ilişkiye yoğunlaşmakta ve bu dönemde çekilmiş en net muhafazakârlık eleştirisi sunan film olarak öne çıkmaktadır. Filmde gelecek, yeryüzünde kaosun hâkim olduğu, yeraltında ise yıkımdan sağ kalan bir grup Amerikalı muhafazakârın milenyarist, otokrat, faşist bir yönetim altında sürdükleri yaşam olarak temsil edilmektedir. Üreme sorunuyla karşılaşan Amerikanlar kendilerine damızlık erkekler bulmaya çalışırken, aykırı fikirleri ve davranışları olanlar hızla ortadan kaldırılır, 'çiftliğe' gönderilerek öldürülür. Hoparlörden sürekli duyurulan propaganda mesajları ve yemek tarifleri, herkesin yüzündeki 'beyaz' makyajlı maskeler, komite üyelerinin soğukkanlı duruşları, filmin bugüne karşı tavrını belirginleştirmektedir. Film bireyler arasında var olan ve yalancılıkla anlam bulan kurumsallaşmaya başlamış faşist ilişkilere karşı 'yamyamca' bir saldırıyı meşrulaştırır ve onları ti'ye alır. Logan's Run yıkım sonrası dünyanın durumunu ütopya/ distopya dikotomisi çerçevesinden ele almaktadır. Arzuların 30 yaşına kadar giderildiği, her şeyin serbest olduğu bir dünyadan daha uzun yaşam arzusu ile ayrılış, bütün arzuların giderildiği mini cennetin sınırlarının kırılıp, eski, doğanın işgali altına girmeye başlamış dünyanın keşfedilmesi ile bir sona ulaşır. Film kapalılıktan açıklığa, muhtemelen de artık her arzunun giderilmeyeceği bir dünyaya geçişi özgürlük olarak ortaya koysa da ütopik olanın kazanımları ile geçmişin 'büyük' dünyası arasında bir denge kurmak arzusunda değildir. Beneath the Planet of the Apes (Ted Post, 1970) çatışma unsurunu bu sefer savaş çığırtkanı goriller ve onlara yol gösteren orangutanlar ile yüksek düzeyde dini itkilerle hareket eden, bombaya ve yıkıcı güce tapınan fundamentalist insansılar arasında nesnelleştirmiştir. Tıpkı diğer filmdeki gibi tarihi telafi çabalarına girişmez; dahası yıkım yeniden tekrarlanır ve bu, insanların mutasyon geçirmiş, çirkin, kalıntıları kadar, maymunlar arasındaki aşırılıkçı, savaş yanlılarının yüzündendir. Emperyalist istilalar ya da öğrenci hareketleri gibi zamanının toplumsal 
çatışma görüngülerini işleyen film, şimdiki zamanın 'olağan' gibi görünen gidişatını farklı bir zamanda yeniden düzenleyerek bugüne bakışı sorgular. Ancak bu sefer kötülüğü daha genetik gören bir düzeye doğru geriler. Battle for the Planet of the Apes, 2000 yılı öncesinde yapılmış serinin son filmidir. Film insanlar ve maymunlar arasında gerçekleşen son savaşın nükleer saldırılar ile bitmesinden sonraki dönemde, kentte, yeraltında yaşayan mutasyon geçirmiş insanlar ile doğal alanda bir komün yaşamı süren maymunlar (ve onların arasındaki insanlar) arasındaki çatışmayı ortaya koyar. Maymunların zaferi sağlansa da maymunlar arasındaki bir grubun, gorillerin, en az insanlar kadar acımasız ve kötü olabileceği açığa çıkar. Her iki kötü grup da yenildikten sonra insanlar ve maymunlar arasında birlikte yaşamın mümkün olduğu ortaya konur ve bazı kuşkular bulunsa da tarihin alternatif bir gelişim izleyebileceği kabul edilir. Bir diğer I am Legend uyarlaması The Omega Man, yıkım sonrası dünyayı geçmişi tümüyle reddedip onun kalıntılarına karşı mezar kazıcılar olarak şekillenen fundamentalist 'aile' ile başlangıçta kötümser, ancak Lisa ve çocuklarla karşılaştıktan sonra iyimserleşen Neville'in yapıcılığı arasındaki çatışma olarak serimler. Film yenilik arzusunu ve bunun gerçekleştirilmesini çocuklarla temsil edilen bir saflık gereksinimi ile göstermektedir. Z.P.G., yıkım sonrası dünyayı otokrat yönetimlerin, bireylerin arzularına (özellikle üreme) karşı birleşmiş olduğu dumanlı, verimsiz, radyoaktif bir dünya olarak tahayyül etmektedir. Dünyanın ve toplumun iyiliği için yeni çocuk yapmanın yasaklanması baskıcı bir unsur olarak bireylerin özgürlüğünü yok sayan bir uygulama olarak gösterilirken, film gerçekten artan nüfusun dünya üzerindeki etkilerini tartışmaya açmaz ve geçmişi nostaljik bir perspektifle ortaya koyar. Zardoz ütopya fikrine karşı mesafeli bir tavır takınır. Bir açıdan sonsuz sefahat içinde yaşayan burjuvazi olarak görünüm kazanan "Eternals" ve vahşi bir dünyada hayatta kalmaya çalışan üretici "Brutals" arasındaki ayrışmayı, Brutals'ları denetlemek için kullanılan "The Exterminators"ler arasında bulunan Zed ile çözüme kavuşturur. Sonsuz sefahatin durağan, ölümsüzlüğün bir lanet olduğu fikrinden hareketle, bu dünyaya 'sahip olan' burjuvaziyi eleştirip 'karşıtların birliği' fikrini savunsa da sonunda ütopya idealinden uzaklaşır. Umudu bir kurtarıcı figürüne aktarır. The Ultimate Warrior yıkım sonrası dünyayı, kaynaklar için mücadele eden, halen metropolde yaşayıp orayı daha güvenli bulan bölünmüş topluluklar arasındaki mücadele alanı olarak betimlemektedir. Topluluğa karşı şüpheci bir yaklaşım kuvvetlendirilirken, sadece ayrıcalıklı ve özel yetenekli olanların kurtulduğu ütopik bir son öne sürülmektedir. Geleceğin dünyası geçmişin kötülüklerinden arınmış değildir; yeni insan, yeni doğa daha 'dayanıklı'dır. Damnation Alley (Jack Smight, 1977), Sovyetler Birliği'nin saldırısıyla başlayan bir nükleer savaş sonrasında, böceklerin mutasyon geçirip tehditkâr olmaya başladıkları ekseni bozulmuş dünya tasavvur etmekte ve Amerikan mitini yeniden canlandırmaya çalışmaktadır. Deathsport, geleceğin yıkım sonrası dünyasını, ölüm sporlarının yapıldığı, 'uygarlığın' küçük şehir devletlerine bölündüğü, mutasyon geçirenlerin çorak arazilerde hayatta kalmaya çalıştığı kaotik ve fantastik bir dünya olarak betimler. Ölümüne mücadele ilk başta yıkıcı ve tehlikeli bir arena olarak görünse de, aslında eski Roma dönemi gladyatörlerinin çarpıştığı kolezyum ile ikonik benzerliğe sahiptir ve hayatta kalan başarılı ve iyi olduğunu kanıtlamaktadır. Film ağırlıkla modern toplumsal yaşamın rekabetçi niteliğine dönük endişelerini yansıtır. Ravagers geleceğin yıkım sonrası toplumunu bir kuralsızlık toplumu olarak betimler ve yıkıcı/talancılar olarak 
"Ravagers" ile mağaralarda saklanan "Flockers" topluluklarını farklı biçimlerde eleştirir. Dahası yerleşik topluluk kurmanın, mutluluk adaları/gemileri inşa etmenin baskıcı olan yönüne dikkat çekilirken, orada bir yerde, yeniden üretken olmaya başlayan dünyanın nimetlerinin bulunduğu, serbestçe araştııılması gereken bir yenilenme, yaratıcılık mekanları olduğunu vurgular ve ütopik arayışı destekler. Quintet geleceğin dünyasını bir oyun metaforu üzerinden betimler. Oyun tüm 'heyecanıyla' sürmektedir. Yenilenler oyundan 'çıkmakta'dır ve sonunda kalan, yaşayanlar, yıkım sonrasında hayatta kalanlar, 'kazanmışlardır' ama asıında kazanılan hiçbir şey yoktur. Film bu hiçliğin melankolisine dairdir.

Silent Running, savaş sonrasında geçici bir süre için uzaya taşınan insanlığın, doğaya verdiği zararı vurgulayan, dahası insan ve doğa arasında bir seçim yapmak gerektiğinde de doğayı tercih eden bir yönelimi ifade etmektedir ve ekosisteme, doğanın korunmasına yönelik güçlü bir vurguyu ilk öne çıkaran, ekolojist bir yapıttır. Dönemde ilk kez post-apokalipsin yarattığı yalnızlığı ele alan The Noah (Daniel Bourla, 1975), nükleer savaş sonrası hayatta kalan tek kişi olan Noah'ın yalnızlığını dayanııır kılmak için geçmişin imgeleri ve hayali arkadaşlarını yeniden yaratışını resmeder. Yitip giden uygarlık yaşlı bir adamın zihninde çılgınca bir karmaşadan ibarettir. Buck Rogers in the 25th Century (Daniel Haller, 1979), bir uzay fenomenini incelemek için gönderilen Buck Rogers'ın, beş yüz yıllık bir dondurulmanın ardından nükleer bir felaketle yok olmuş ancak yeniden inşa edilmeye başlanmış dünyasında uyanışını ve yeni dönemin uluslararası ilişkilerine dahil oluşunu konu alır. Film, düşman olarak Uzak Doğulu görünümlü figürleri ortaya koyarken, ticari ilişkilere şüpheci yaklaşır ve 'yeni' dünyanın 'eski Amerika'dan öğreneceği çok şey olduğunu göstermeye çalışmaktadır.

\subsection{0'ler: B sınıfı Filmlerinin Yükseliși: Çöl Savașları}

Post-apokaliptik filmler, 1980'li yıllarda önemli bir artış göstermektedir. Bunun en karakteristik göstergesi, B filmi olarak nitelendirilen, kesme-biçme, cinsel sömürü amaçlı, düşük bütçeli filmlerin sayısındaki artıştır. Bu filmlerde muhafazakâr ton baskındır ve hayatta kalmak en önemli şeydir; doğru değerlerle donanmış olmakgerekli koşuldur. Bunun yanı sıra feminist hareketteki yükseliş, kimi zaman korku ve endişe kaynağı olarak filmlerdeki güçlü kadın imgesiyle kendini göstermektedir. Distopik eserler üretilse de bunlar sayıca azalmaya başlamıştır. Televizyon önemli bir kitle iletişim aracı olarak, kitleleri kontrolde önemli bir yere sahiptir. Teknolojiye karşı şüphe ise, uzun yıllar seri olarak çekilecek bir temanın ortaya çıkmasına olanak tanımıştır.

B sınıfı sömürü filmlerinde öncelikli sorun her daim kaosu düzene çevirmedir. Aftermath (Steve Barkett, 1982) ve sonradan benzer bir temayla yenilenmesi olarak Survivor (Michael Shackleton, 1987) uzaydan dönen bir astronotun "onur, sevgi ya da adalet" gibi unsurlar için savaşını konu edinmektedir. Kaosun düzene çevrilmesi sorunu, başarılı bir Avustralya yapımı olan George Miller'ın Mad Max serisinin (1979, 1981, 1985), kopyalarının ortaya çıkmasına sebep olmuştur. Zırhlı arabalar, takip sahneleri, çöl, mutasyon geçirmiş yaratıklar, su ya da petrol için savaş hem erkeklere tehlike 
arz eden hem de doğurganlık simgesi olarak denge arayışıyla bir bütünün parçası olarak ortaya konan Amazon kadın ikonları bu filmlerde kendini göstermektedir. Farklılıklara tahammülsüz Warriors of the Apocalypse (Bobby A. Suarez, 1985), 'Mülkiyet'in egemenliğini kaosun bitimi olarak gören Wheels of Fire (Cirio H. Saniago, 1985), Amerikan mitinin yeniden diriltilişi ve ‘sömürülen' erkeklerin eşitlik arayışı olarak America 3000 (David Engelbach, 1986), geleceğin Nazi tehdidi altında olduğunu belirten fantastik Future Hunters (Cirio H. Santiago, 1986) ve aynı yönetmenin Mülkiyet adlı bir grubun petrol bölgeleri üzerinde egemenlik kurmaya çalışmasını ve buna karşı mücadeleyi anlatan Equalizer 2000 (1987), çekimleri Türkiye'de yapılan, vaat edilen toprakların arayışı olarak Land of Doom (Peter Maris, 1986), ayrılıkları bitirmeye çalışan Desert Warrior (Jim Goldman, 1988), "Son Erkek"in hayatta kalması için yapılan mücadele olarak Phoenix the Warrior (Robert Hayes, 1988) ve gelecekte tek eğlenceli şeyin Amerikan futbolunun daha vahşi bir türevinin olduğu ve ilk defa Uzak Doğulu bir ana karaktere sahip olan Blood of Heroes (David Webb Peoples, 1989), bu filmlerin tipik örnekleridir.

Dönemdeki filmlerde, virüs, bulaşıcı bir hastalık nedeniyle gerçekleşen kıyamet fikri de varlığını göstermektedir. Dead Man Walking (Gregory Dark, 1988) zengin bir adamın kızının suçlular tarafından kaçırılmasını konu edinmektedir. Amerika'daki şirketlerin artan gücüne dikkat çekip, "Tüccarlar" tarafından yönetilen bir polis devleti tasavvurunda bulunan Parasite (Charles Band, 1982), sadece erişkin insanları öldüren bir virüs ve şeytani şirketin yıkıcı politikalarını eleştiren City Limits (Aaron Lipstadt, 1985), mutasyon geçiren canavar ve tıbbi deneylerin yarattığı tehlike ve hükümetin bundaki rolüne değinen Creepozoids (David DeCoteau, 1987) bu filmlere örnektir. Kıyameti virüs tehlikesine bağlasa da asıl tehlikenin aileye dönük olduğunun savunan film ise Cyborg'tur (Albert Pyun, 1989). The Terror Within (Thierry Notz, 1989), Alien (Ridley Scott, 1981) gibi filmlerde öne çıkan, bastırılan ve sıklıkla insan hatası, onun sınırları aşmasıyla ortaya çıkan yıkıcı yaratığın yok edilmesi temasını merkezine alır. Filmde bulaşıcı hastalığa karşı tedavinin doğru yere ulaşması ile kahramanın ailesini yok edenin ortadan kaldırılması (toplumun hastalıktan kurtarılması), koşut bir süreç olarak değerlendirilmektedir.

Dönemin modası olarak öne çıkan patenler çoğunlukla bir eleştiri aracı olarak filmlerde yer bulmuştur. Sadece patenin ulaşım aracı olarak kullanıldığı, faşist bir yapıya karşı garip ve cinsel ritüelleri olan bir dini örgüt (onlarla dalga geçerek) ayaklanmasını resmeden Roller Blade'e (Donald G. Jackson, 1986) karşılık, Solarbabies (Alan Johnson, 1986) faşist yapıya en eğlenceli şey olarak paten kayan yetimhane çocuklarını isyanını konu edinmektedir. Gelecekte en değerli şey sudur. Artık yağmur yağmamaktadır. Faşist Protekterya ortadan kalktıktan sonra tanrısal gazap da son bulmakta ve yağmur tekrar yağmaya başlamaktadır. Faşizm ve polis devletine daha ciddi eleştiriler getiren başka filmler vardır. Escape from Safehaven (Brain Thomas Jones, James McCalmont, 1989) baskıcı topluluktan kaçmanın güvenlik sağladığı düşüncesinden hareket etmektedir. World Gone Wild (Lee H. Katzin, 1987) suyun en değerli şey olduğu, beyazlar giyinmiş, Nazi benzeri bir örgütün saldırganlığı ve buna karşı koyan, bu iş için bir araya getirilmiş silahşorları konu edinmektedir. Dinin kurumsallaşmış biçimi eleştirilirken, onun daha 
mistik yönü 'son savaşın' ardından dünyanın arındığı bir çerçeveye gönderme yapmaktadır. Cherry 2000 (Steve de Jarnatt, 1987), temel olarak insan ve makine ilişkilerine, savaşın etkisinin ve nedeninin tam belli olmadığı, ekonomik kriz içinde boğuşan bir post-apokaliptik dünyaya eğilir. Böylece aradığı ideal ilişkiyi bir makinede bulan, onun nostaljisini yaşayan bir adam söz konusudur. O bozulmuş robotunun bir kopyasını 'kuralların olmadığı' western filmlerindeki ya da ellilerde Amerikan kent yaşamının süregittiği 'nostalji adacıklarında' arar ve sonunda gerçek bir kadını ve ilişkiyi bulur. Crime Zone (Luis Llosa, 1989), kıyamet sonrası dünyadaki en büyük tehlike olarak otoriterleşme ve baskıcı polis devleti yapılanmalarını görmektedir. The Running Man (Paul Michael Glaser, 1987), yıkımın etkilerini salt ekonomik düzeyde ele alır, insani kayıpları belirtmez ve gelecekteki kıyameti ekonomik ve bununla ilişkili olarak sanatsal, toplumsal bir kıyamet olarak ortaya koyup gösteri toplumuna karşı eleştirel bir yaklaşım sergiler. Film teknolojiye dönük korkuları beslemekle birlikte bu teknolojiyi kullanan medya ve hükümeti hedef tahtasına yerleştirir. Eser gelecekteki en büyük yıkım olarak hakikatin kaybını işaret eder. Masum insanların katledildiği ancak kurgulanan görüntülerde bütün emre uymayanların düşman ilan edildiği bir gelecekte, asıl tehlikenin bu gösteri toplumu olduğunu belirtir. Rising Storm (Francis Schaeffer, 1989), yıkım sonrası dünyayı, dini aşırıcılığın, evanjelist-fundamentalizmin yükselişe geçtiği, ABD'yi yönettiği faşist bir yapılanma olarak sunmaktadır. Reagan'ın temsil ettiği muhafazakârlığa karşı daha liberal bir Amerika özlemini dile getirir ve tıpkı The Running Man'de olduğu gibi değişimin ancak önemli bir kitle iletişim aracı olan televizyonun kontrolü ile insanların hakikate ulaştıkları anda gerçekleşeceğini, insanların bu anda isyan edeceğini ön varsayar.

Dönemde daha ayrıksı filmler de çekilmiştir. Yıkımı döngüsel bir olgu olarak gören ve kuyruklu yıldızın geçmesiyle bir anda kuma dönüşen insanları, tesadüfen hayatta kalan "kirlenmemişleri" varlıklarını sürdürmek için kullanan kötü bilimcileri konu alan Night of the Comet (Thom Eberhardt, 1984) bilime karşı şüpheyi bilim insanlarına doğru genişletmektedir. Robot Jox (Stuart Gordon, 1989) dünyadaki siyasi sorunların robotlar aracılığıyla, arenalarda çözüldüğü daha kansız, uzlaşmacı bir siyaset önermektedir. Robot Holocaust (Tim Kincaid, 1986) robotların yıkıcı bir şekilde ortaya çıktığı bir düzleme işaret ederken, Wired to Kill (Francis Schaeffer, 1986) bireysel silahlanmayı kutsamaktadır. Hell Comes to Frogtown (Donald G. Jackson, 1988) ise yeni bir savaş daha yapılması için kadınlar tarafından doğurganlık artışı için kullanılan bir "son erkeğin”, görünüşleri Orta Doğululara benzeyen kurbağa kentinden doğurgan kadınları kurtarmasını ele almaktadır. Radiactive Dreams (Albert Pyun, 1986), yıkım sonrası dünyayı, babaları tarafından on beş yıl boyunca saklı kaldıkları sığınakta güvenli bir şekilde yetiştirilip, 1950’lerin dedektiflik hikâyeleri eşliğinde büyüyerek geçiren iki gencin komik hikâyesi eşliğinde ele alır. Çocuklar ellerindeki son kalan nükleer silahı harekete geçirecek anahtarla bu güce erişmek isteyen tarafların hedefine yerleşirler. Film nükleer silahların yıkıcı etkisi konusunda net bir eleştiride bulunmaktan uzaktır.

Dönemin öne çıkan filmi ise The Terminator'dür (James Cameron, 1984). Filmin önemli kısmı 'şimdiki zaman'da geçmektedir. The Terminator insan-makine ilişkilerine karşı güçlü biçimde kuşkuları dile getirir. Kötü ellerde teknoloji yıkıcıdır. Otomasyon 
teknolojileri, makinelerin dış katmanlarının insana benzemesiyle kimlik ve benlik karmaşasının sonuçları yıkıcı, yok edici bir maskülen figürle canlılık kazanır. Film geçmişe karşı nostaljik değilse ve geçmişi düzeltilecek bir şey olarak görmese de onu gelecek için araçsallaştııı, makinelerin gerçekleştirdiği yıkımı kaçınılmaz görerek, işlerin yolunda gitmesi için mücadele eder. Savaşçı etiği ise Steel Dawn (Lance Hool, 1987) filminin merkezindedir. Eser nedeni belli olmayan bir savaşın çöl dünyası olarak tasvir ettiği post-apokaliptik dönemi, Amerikan 'öncü miti'nin yeniden gerçekleşebileceği, gerçekleşmesi gerektiği bir süreç olarak görmektedir.

\subsection{0'lar: Alternatif Tarih Akıșları, Geleceği Geçmiș Yapmak}

Post-apokaliptik filmler 1990'larda bolca üretilmiştir. Blockbuster filmlerin üretimi ise daha fazladır. Dönemin modası dövüş sanatları ve vücut geliştirme, bedenin ifşası hemen pek çok filmin arka fonunda yer almaktadır. Ayrıca sinema ve edebiyatın çeşitli klasikleri uyarlama/esinleme ile post-apokaliptik dünyaya aktarılmıştır.

Dönemin ilk yarısı özellikle B-filmlerinin çokça üretildiği yıllardır. Hardware (Richard Stanley, 1990) kıyamet sonrasında makine ve robotları esas tehlike olarak görmeye devam ederken, yıkımı dinsel bir bağlam ve deterministik düzlemde ortaya koymaktadır. A Nymphoid Barbarian in Dinosaur Hell (Brett Piper, 1990) ilkelliğe dönüş metaforu kullanıp, yeni dünyayı dinozorların egemenliği altındaki yer olarak betimlemektedir. Dune Warriors (Cirio H. Santiago, 1990) Akira Kurosawa'nın Yedi Samuray (1954) filmindeki gibi bir grup savaşçının tehlike altındaki köylüleri/koloniyi canları pahasına korumasını ele alırken, The Final Sanction (David A. Prior, 1990), soğuk savaş sonrası dönemde savaşın mutlak yıkım tehlikesine karşı, barışçıl ve hümanist bir siyaset önerir. Ölüm/ölüm yerine yaşam/yaşam politikasını vurgular. Aftershock (Frank Harris, 1990), yıkım sonrası dünyada ironik biçimde "barışın nasıl korunduğunu" öğrenmeye gelen sarışın bir uzaylı kadının iyiler ve kötülerle karşılaşmasını konu alır. Ultra Warrior (Augusto Tamayo San Román, Kevin Tent, 1990) dönemde öne çıkan ABD'nin uygulamaya çalıştığı yıldız savaşları savunma sistemini çağrıştıran, felaketi bu savunma sisteminin tetiklediği nükleer yıkıma dayandırmakta, mücadeleyi evrenler arası bir düzleme yerleştirmektedir. Omega Cop (Paul Kyriazi, 1990), güneş patlamalarına dayandırdığı kıyameti, toplumsal yapılanmanın çöküşü, suç ve düzensizliğin yükselişi bunun etkisiyle de totaliter yapıların tüm dünyada egemen oluşuyla ilişkilendirmektedir. Circuitry Man (Steven Lovy, 1990), yıkımın sebebi olarak insanın doğayla kurduğu yıkıcı ilişkiyi göstermektedir. Neon City (Monte Markham, 1991), John Ford'un Stagecoach (Posta Arabası, 1939) filmini çağrıştıracak biçimde, birbirinden farklı, polis, eski polis, seri katil, bilimci, fahişe, zengin bir kadın ve suçlu bir kadın gibi tiplemeleri bir araya toplayıp, onların güvenli Neon Şehri'ne bir yönüyle yerlilere benzeyen mutantları ve ekolojik tehlikeleri aşarak ulaşmasını konu alır. Devam filmleri olarak The Terror Within 2'de (Andrew Stevens, 1991) 'içerdeki terör' devam ederken, dini kurumlara karşı şüpheci yaklaşım sürmekte, Return to Frogtown (Donald G. Jackson, 1992) insanlığın tümünün kurbağa olması tehlikesini engellemeye çalışan kişilerin macerasını konu almaktadır. Prototype (Philip J. Roth, 1992), yıkım sonrası 
dünyada, artan düzensizliğe karşı geliştirilen cyborglar vasıtasıyla, insan olmanın anlamını tartışmaktadır. TC 2000 (T. J. Scott, 1993), yıkımı ekolojik felakete dayandırır ve post-apokaliptik dönemi zenginlerin yeraltında refah içinde yaşadığı, fakirlerin ise yerüstünde açlıkla boğuşurken yeraltından yiyecek çaldığı sınıfsal kutuplaşma dönemi olarak betimlemektedir. American Cyborg: Steel Warrior (Boaz Davidson, 1993), yıkım sonrasında kısırlaşan insan imgesine karşılık, hâkim duruma geçen robot ve yapay zekâ sorunsalını merkeze almaktadır. Amerika artık kurtulmanın gerektiği yerdir. Sovyetlerin ABD'yi işgal ettiği alternatif bir tarih öneren ve Lost City'nin yeni Rock'n Roll kralını bulmak için adayların mücadele ettiği parodik Six-String Samurai (Lance Mungia, 1998) kısmen, Fist of the North Star (Tony Randel, 1995) ve Dragon Fury (David Heavener, 1995) bütünüyle dövüş sanatlarının merkezi konumda olduğu bir dünya resmetmektedir. Haklılık ve hayatta kalma büyük ölçüde dövüşteki yeteneğe göre şekillenmektedir. Dönemde devasa robotlar da unutulmamıştır. Robo Warriors (lan Barry, 1996), yıkımı uzaylı robot istilasına bağlamaktadır ve yıkım sonrası dünyayı Nazi benzeri bir otokratik yönetim olarak temsil etmektedir. Büyük bir bütçe ile çekilse de gişede başarısız olan Barb Wire (David Hogan, 1996), Michael Curtiz'in Casablanca (1941) filmini çağrıştırmakta, yıkım olgusunu Amerika'daki iktidarın yerini faşist bir yapılanmaya bırakması olarak görmektedir. Mindwarp'ta (Steve Barnett, 1992) öne çıkan, post-apokaliptik dönem insanının iç sıkıntısı, bunun giderilmesi için yönelinen sonsuz güç istenci, bütün arzuların doyurulduğu bir sanal dünya tasarımıdır. Gerçeklikten 'kaçış' açık bir olgudur ancak bu ideolojik olarak 'açık' durum bilişsel bir dönüşüm yaratmamaktadır. Bleak Future (Brain S. O'Malley, 1997) ise yıkımın parodisini yapmakta, kendisini Antik zamanın kehanetvari Kaynak'ını bulmaya adamış Slangman ve onun çevresindeki birkaç kişinin yolculuğunu konu almaktadır; sonunda bulunan saf ölümdür.

Blockbuster filmlerde merkezi tema, tarihin değişebileceği önerisidir. Bu türden tematik vurguda Sovyet Birliği'nin beklenmedik çöküşünün yarattığı geleceği imgelemede radikal değişim önemli rol oynamaktadır. Bu yüzden filmler gelecekteki gerçekleşmiş yıkım olgusunu bir sonuç, onun değiştirilmesi için bugünü yeniden düzenlemeyi zorunluluk görmektedir. Böylece bu filmlerin ele aldığı zaman, geleceğin geçmişi olan zamandır. Frankenstein Unbound (Roger Corman, 1990) yıkım sonrası dünyadaki savaşı bitirecek büyük bir silahın icadı ve onun yarattığı zaman kırılmasıyla, Frankenstein hikayesini paralel olarak ele almaktadır. Nasıl Frankenstein'ın yaratımı insanın 'tanrıcılık' oynadığı bir ihlal ise, savaşı bitirip homojenite yaratacak bir icat da bu türden bir ihlaldir ve karşılığı insanlığın tümden yok oluşu olacaktır. The Terminator: The Judgement Day (James Cameron, 1991), ilk filmden farklı olarak, sadece tarihin kendi rayında tutulması değil, tarihin alternatif seyrinin gerçekleşmesi için yapılan bir mücadeleyi konu edinir. Tarih olumsaldır. Filmin ütopik sonu aslında dengeli şimdiki zamanın uzatılması olarak anlam kazanmaktadır. Artan otoriterlik korkusu, polis şiddetinin Terminatör tarafından cezalandırılması ile karşılık bulurken, akıl hastaneleri gibi baskı aygıtlarının eleştirisi söz konusudur. Güçlü kadın imgesi ise bir tehdit değildir; gelecekteki insanlığın kurtarıcısının yol göstericisidir. Twelve Monkeys (Terry Gilliam, 1995) yıkıma dönük tarihsel eğilimi, düzeltilmesi ve kaçınılması gereken, kökeninde bilimcilerin bulunduğu bir hastalık olarak görmektedir. Cole geçmişin ve geleceğin 
şekillenişinin bir aracı haline gelmektedir. "Sigorta" geleceğin geçmişe müdahalesiyle mümkündür. Film tarihi düzeltmeci olarak ilerliyor görünse de tarihin düzeltilme çabasını gelecekteki görece daha sağlıklı toplumun ortaya çıkışındaki ara süreç olarak göstermektedir. Bu yüzden tarih değiştirilemiyorsa da onunla 'yüzleşildiği' için gelecek daha güvenli bir şekilde akmaya devam etmektedir. Star Trek: First Contact, (Jonathan Frakes, 1996) tıpkı 12 Maymun gibi tarihi düzeltilmesi gereken bir 'sapma' olarak değerlendirir ve kahramanlarını alternatif tarihi düzeltmek için zaman yolculuğuna çıkartır. Felaketin geçekleşmesini engellemek, uzaylı ırklarla ilk temasın kurulmasını sağlamakla mümkündür. Bu yüzden, genel olarak Star Trek'in modernizm ve aydınlanmacı geleneğine uyumlu biçimde, kahramanlar korumacı değildir ve insanlığı daha yeni ve iyi bir duruma taşıyacak olan bir tarihsel gelişimin gerçekleştirilmesi için mücadele etmektedirler.

Pek çok post-apokaliptik filme ilham veren Akira Kurosawa, Dreams (1990) adlı eserinde farklı türden hikayeleri ele alsa da ilkinde daha apokaliptik vizyon olmak üzere, Kırmızı Fuji Dağı ve Ağlayan Şeytan öykülerinde post-apokaliptik temaları işlemektedir. Öykülerde distopik gelecek tasavvur edilmekle birlikte, filmin sonunda ütopik ve insanın yaratıcı enerjisine güven öne çıkmaktadır. Rüyalarda öne çıkan nokta sorumluluk, kefaret ve acıdır. Bilim insanı sorumluluğunun farkına varıp kefareti yüklenir (intihar eder), yıkım sonrasında kadın, erkek ve çocuklar yıkımın sorumluluğunu taşımasalar da acısını çekerler. Ağlayan Şeytan’ta ise insanın yarattığı cehennemsi dünya onun sonsuz acılarının yaşandığı mekân haline gelir. Mutasyon geçiren doğa ve insan, halen hiyerarşik olan kötülük, yamyamlık, şimdiki zamandan radikal biçimde farklı bir dünya tasavvuruyla yabancılaştırma sağlar; dini ve seküler yönden insanın dikkatli ve sorumlu davranması gerektiğine dikkat çeker. Omega Doom (Albert Pyun, 1996), insanın yokluğu fikriyle çekilmiş, Akira Kurosawa'nın Yojimbo (1961) adlı eserinin farklı, post-apokaliptik uyarlamasıdır. İnsan ve robotlar arasındaki savaşı robotlar kazansa da, robotlar arasındaki savaş devam eder. İnsanın ardında bıraktıkları da en az insan kadar yıkıcı davranmaya devam etmektedir ki, bu yönüyle onlar hem görünüş itibariyle insanlara benzemeleri, hem de yıkıcı kültürü devam ettirmeleri bakımından insanın yokluğunu 'aratmazlar'.

Rachel Talalay'ın Tank Girl (1995) filmi post-apokaliptik filmlerde çok görülmeyen biçimde kendisiyle barışık, hiperaktif kadın kahraman imgesine sahiptir. 2022 yılında dünyaya çarpan bir göktaşı dünyadaki yaşamı ortadan kaldırmıştır. Film daha heterojen bir dünya tasavvuruna sahiptir, şirketlerin egemenlik tehlikesini gelecek için en büyük tehdit olarak görmektedir. Waterworld (Kevin Reynolds, 1995), yıkım sonrası dünyayı Tufan imgesini canlı tutacak bir biçimde tasavvur etmektedir. Bir yönüyle cennetimsi bir adaya benzeyen toprağı ancak bu konuda yeterli bilgiye sahip, iktidar hırsından arınmış insanların ulaşabildiği ütopya adası olarak sunar. Ancak ütopyayı homojenleştirici bir ideal olarak sunmaz. Denizci'nin kendi 'toprağı' olan suya dönüşünde olduğu gibi, farklılık diyalektiğine uygun olarak heterojen bir dünya imgesi kurar. Yıkıcı güçlerden arınıp adil, duyarlı ve fedakâr olmakla bu ütopya kazanılabilmektedir.

İç savaş metaforuyla Amerikan mitini yeniden inşa etmek bir başka blockbuster filminin 
konusudur. The Postman (Kevin Costner, 1997), yıkım sonrası dünyanın koşullarını, Amerika'nın bağımsızlık savaşı yürütüp, kolonileri bir araya getirerek, ulusu yeniden inşa ettiği geçmişin tekrarı olarak sunmaktadır. Böylece dağınık ve birbirinden habersiz kalan küçük koloniler, onlara birleştirici ulusal kimliği sunan ideal Amerikan figürü olarak Postacı'yı bulduklarında hemen bir araya gelmeye başlarlar. Postacı bunun 'tılsım'ına sahiptir. Böylece Amerikan ulusal kimliğinin inşası 'asil olmayan' eski satıcıya karşı gerçekleştirilen bir karşı duruşla anlam kazanmaktadır. Sorun liderlik sorunudur ve bu yüzden Postacı ve Bethlehem son kavgalarıyla lideri belirleyecek adımları atarlar. Böylece "Yaşa ve yaşat!" sloganıyla özetlenecek, değer bazlı bir araya getirilmiş insanlar Amerikan kuruluş mitini gerçekleştirir. Son olarak Matrix (Wachowski Kardeşler, 1999), geleceği insan ve yarattığı yapay zekâ arasında çatışmanın gerçekleştiği bir dünya olarak tasarımlar. Artık makineler insanlar için değil, insanlar makineler için vardır. Film tutsaklık ve tersine dönmüş sömürü ilişkileri metaforu yoluyla, gerçekliğin kendisini sorgulatacak bir yabancılaştırıcı etki yaratır. Özellikle internetin, robotik teknolojik gelişmelerin ivme kazandığı milenyal dönüm noktasında gerçek bir sorunu aksiyona dayalı bir anlatı modeliyle sunar; bu yüzden türün sonraki gelişiminde önemli bir etki sağlamıştır.

\section{Sonuc}

Sonuç olarak aşağıdaki tabloda da görüleceği gibi post-apokaliptik filmler farklı türde felaket nedenine dayalı yeniden kurulmuş bir toplum imgesine sahip olsalar da, ana sebep araç ve teknoloji farklı olsa da atom silahlarının kullanıldığı bir savaştır. Sonraki büyük neden insanlarla bağıntılı viral salgınlardır.

Bu türdeki filmler düzenli bir şekilde artış göstermektedir ve bu durum film endüstrisinin bu gelecek korkusunu ciddiye aldığına, bunu çeşitli temsillerde kullandığı/ sorunsallaştırdığına işaret etmektedir. Bu yükselen eğilim 2000 sonrasında da devam etmektedir (Boz, 2018).

Tablo 1. Filmlerin dönemlere göre üretimi ve felaket türleri

\begin{tabular}{|l|cccccc|c|}
\cline { 2 - 6 } \multicolumn{1}{l|}{} & $\begin{array}{c}1950 \\
\text { Öncesi }\end{array}$ & 1950 & 1960 & 1970 & 1980 & 1990 & Toplam \\
\hline Biyolojik & & & & 1 & & & $\mathbf{1}$ \\
Ekolojik Yıkım & & & & & & 4 & $\mathbf{4}$ \\
Doğal Felaket & 2 & & & & 1 & 2 & $\mathbf{5}$ \\
Ekonomik & & & & & 1 & & $\mathbf{1}$ \\
Gizemli/Belirsiz & & & 1 & 2 & 1 & 2 & $\mathbf{6}$ \\
Insan-Makine & & & & & 2 & 3 & $\mathbf{5}$ \\
Nükleer Test & & 1 & 1 & & & & $\mathbf{2}$ \\
Savaş & 6 & 5 & 12 & 23 & 16 & $\mathbf{6 2}$ \\
Uzaylı & & 1 & & & & 2 & $\mathbf{3}$
\end{tabular}




\begin{tabular}{|c|c|c|c|c|c|c|c|}
\hline Virüs & 1 & & 1 & 2 & 5 & 1 & 10 \\
\hline Küresel Isınma & & & & 1 & & 1 & 2 \\
\hline Toplam & 3 & 8 & 8 & 18 & 33 & 31 & 101 \\
\hline
\end{tabular}

Post-apokaliptik filmler tür olarak komik 'son erkek' motifiyle başlamış, fakat ekonomik krizler ve İkinci Dünya Savaşı'nın ardından giderek ciddi konu ve figürlere yönelmiştir. İnsanların nükleer silahları kullanacak kadar 'aptal' olduğu vurgulanmıştır. İnsanın yıkmaya ve yok etmeye eğilimli olduğu yargısı bu filmlerde hâkimdir. Çok özgül muhafazakâr yapımlar dışında, savaşı kimin çıkardığı, ilk bombayı kimin attığı önemsizdir. Kıyamet sonrası kahraman ilk başta, her şeyin bedava olması, belirli bir ideolojik ve baskı aygıtının olmaması sebebiyle oluşan sınırsız özgürlük fikrinden hoşnut görünür. Sonradan hoşnutluk duygusu yalnızlık duygusuyla dehşete dönüşür. Türün ellilerdeki ilk örneğinden itibaren ırk sorunu temel bir sorun olarak ortaya çıkmaktadır. Hollywood sistematik biçimde "renkli" tenlerden kurtulmaya yönelik siyahları ve öteki milliyetten insanları 'kurban' olarak sunmaya eğilimli görünmektedir. Altmışlarla birlikte yıkıma ilişkin temel sorunsal, zaman yolculuğu temasıyla birlikte bir felaketi öteleme fenomenidir. Geleceğe ait olan yıkımın, ırksal ve sınıfsal sonuçları, toplumu katı bölümlere ayırırken, bu filmler çözümü ilk olarak şimdiki zamanda yapılması gerekli değişiklikler ya da gelecekteki insanların şimdinin insanlarından öğrenmesi gereken beceri, fedakârlık, cesaret olarak resmetmektedir. Filmlerde hâkim olan, dönemin yükselen sınıf hareketiyle de ilişkili olarak uzlaşma ve harmoni siyasetidir. Yetmişler türdeki eleştirel dozun artışa geçtiği yıllardır. Her ne kadar şimdiki dünyanın sorunları özgül olarak 'erişkinlere' yüklense ve post-apokaliptik dönemde sadece gençlerin hayatta kaldığı, özgürlük dünyaları ele alınsa da çok geçmeden bu eğilim karamsarlığa dönüşmüştür. Artık toplum kasvetli yalnızlık içindeki bireyin kendi zihninde konuşmaya devam ederken, yıkım olgusu toplumsal kuralların daha sıkı uygulanmasına, daha katı cezaların yürürlüğe konulmasına yol açmaktadır. Bozulmuş, yabanileşmiş mekân ile baskıcı toplumsal sistem arasında kalan bireyler için gelecek ütopik, fantazmik bir iyimserlik dışında çok mümkün görünmemektedir. Seksenlerde ise hızla çoğalan B-filmleri, geleceği artık daha tehditkâr görmekte, hayatta kalma sorununu temel sorun olarak sunmaktadır. Dönemin filmleri için teknoloji ve kitle iletişim araçları distopyanın kurumsallaşmış halidir. Kadın hakları hareketi, tehditkâr kadınları ortaya çıkarırken, erkekler masum, köleleştirilmiş, eşit haklar talep eden, bir elmanın iki yarısı olarak değer kazanmak istemektedir. Tehdit ve tehlike geçmişin dirilen tehlikeleriyle anlam kazanmıştır. Nazi simgeleri ve uygulamaları kötüleri tanınır kılmak için kolay bir ikonografi sağlarken, şirketlerin artan gücü, hakikatin giderek kaybedildiği, gerçekleri gizleyen bir medya tehlike olarak addedilmektedir. Su en değerli şey olarak ortaya çıkarken, insanlara 'küsen' verimsizleşen toprak ve bu verimsizleşmenin kaynağı olarak yağmur yağmaması, toprağın kutsanmaması, insanların 'lanetlenmişlik”lerinin göstergesi olur. Gündelik hayatın her alanını saran teknolojik aygıtlar ise, görünüşte insanların onları kontrol ettiği ama aslında onların insanları kontrol edip uyuşturduğu fikrine işaret etmektedir. Doksanlarda, Doğu Blokunun dağılması ve dünya siyasetinin tek kutuplu hale gelmesi, geleceğe daha farklı gözle bakmaya yol açmıştır. Nükleer savaş olasıllığı halen en büyük tehlike olarak görülse de zaman yolculuğu vasıtasıyla bazı olayları değiştirmek, tarihi alternatif olarak yeniden şekillendirmek mümkündür. 
Altmışların geleceğe giden, kıyameti gören insan imgesinin yerine doksanlarda kıyamet görmüş olanların geçmişe dönüp tarihin akışını değiştirme çabası bilişsel bir etki yaratmaktadır. İnsanın tarihi ve zamanı kontrol altında tuttuğu, gerekli iradeyi gösterirse geleceğin farklı olacağı fikri daha fazla hâkim olmaya başlamıştır. Bunun dolaysız sonucu ise geleceğin bir 'geçmiş' olma intimalidir.

Koch'un tanımladığı kıyamet ideolojisi özelliklerinin dağıımı filmlerde şu şekildedir:

Tablo 2. Kıyamet ideolojisi özelliklerinin filmlere göre dağılımı.

\begin{tabular}{|l|c|c|c|c|c|c|c|c|}
\hline $\begin{array}{l}\text { Kıyamet } \\
\text { İdeolojisi } \\
\text { Özelliği }\end{array}$ & 1. & 2. & 3. & 4. & 5. & 6. & 7. & 8. \\
\hline Film Sayısı & 26 & 100 & 41 & 85 & 23 & 9 & 92 & 85 \\
\hline
\end{tabular}

Kıyamet ideolojisinin birinci özelliği, İkinci Dünya Savaşı sonrası özellikle seksenlerin başına kadar filmlerde kendine yoğun şekilde yer bulur. Bunun anlamı gerçekleşen kıyamet sonrası dünyanın bile yeni bir yıkım ile son bulacağı korkusunun devam etmesidir. Bu korku seksenlerden sonra daha az filmde kendine yer bulmaya başlar. İkinci özellik ise bütün filmlerde bulunur.

Filmlerin önemli bir kısmında tarihin belirli bir amaca dönük gerçekleştiğine dair bir temsil, dolayısıyla determinist bir tarih anlayışı vardır. Bununla birlikte filmlerin çoğu tarihi bu türden bir sorunlar silsilesi olarak görmez. Filmlerin büyük bir kısmı dini anlamda olmasa bile yoğun biçimde şeytanlaştırımış ya da meleksileştirilmiş figürler kullanarak bir tür iyilik/kötülük karşıtlığı yaratır. Cennetimsi, her şeyin yeniden düzene girdiği kurtuluş türü hemen hemen filmlerin dörtte birinde görülür. Daha az sayıda filmde ise Tanrı krallığının tezahür ettiği bir son görülür. Beşinci ve altıncı özellik filmlerin ağırlıkla muhafazakâr ya da daha sağ bir ideolojiye kaymasının işareti olarak belirmektedir. Yedinci özellik filmlerdeki kahraman tipinin genellikle özel, kıyamet sonrasında hayatta kalmasının özel bir anlamı olduğu, onun aracılığıyla sorunların çözüleceğine dair bir çerçeveyi işaret etmektedir. Son özellik ise genel olarak Hollywood sinemasının "mutlu son" olarak da ifade edilecek son sunuşuyla uyumludur ve filmler sonunda kendi etkileşim kurduğu makro ideolojinin genel 'iyiliği' ile son bulur. Bu seyircide katharsis yaratmaya dönük işlev edinmektedir. İstatistiki olarak 2, 4, 7, 8 numaralı özellikler filmlerin büyük kısmında birlikte bulunur. Bu birliktelik ise post-apokaliptik türde kendini tipik bir şekilde gösterecek bir anlatı modeli sunar; felaket gerçekleşmiştir, iyi ve kötü ayrımı belirginleşmiş, çatışma şiddetlenmiştir, ayrıcalıklı bir kahraman tipi bu çatışmanın çözüme bağlanmasında aracı olur ve sonunda mutluluk gelir. 
Filmlerdeki hâkim ideolojinin Giannetti'nin şemasına göre dağılımı şöyledir:

Tablo 3. Filmlerin makro ideolojilere göre dağııımı.

\begin{tabular}{|c|c|c|c|c|c|c|c|}
\hline İdeoloji & Komünist & Sosyalist & Liberal & Merkezci & Muhafazakâr & $\begin{array}{c}\text { Monarşist } \\
\text { Teokratik }\end{array}$ & Faşist \\
\hline $\begin{array}{c}\text { Film } \\
\text { Sayısı }\end{array}$ & 0 & 14 & 35 & 39 & 37 & 1 & 0 \\
\hline
\end{tabular}

Öncelikle pek çok film birbirine yakın ideolojilerle etkileşim içindedir. Örneğin filmdeki hâkim ideoloji liberalizm iken bazen sosyalist ya da merkezci özellikler gözlenebilmektedir. ABD'de komünist ideolojiyi benimseyen hiçbir film bulunmaz. Sosyalist ideolojiye ilişkin özellikler ise önemli sayıda filmde bulunur. Merkezci ideoloji çok sayıda filmde görülmektedir. Fist of the North Starmonarşist, kısmen teokratik filmdir ve başka örnek bulunmaz. Faşist ideolojiye sahip film ise bulunmaz. Görüldüğü üzere ABD post-apokaliptik bilimkurgu sinemasında uçlardaki ideolojik siyasetler kendine yer bulmaz. Esas birikme liberal, merkezci ve muhafazakâr ideolojiler üzerindedir. Savaş Sonrası dönemde pek çok filmde sosyalist ideolojiye sahip filmler görünse de özellikle yetmişlerin ortasından sonra bu ideoloji kendine yer bulmaz. Bundaki tek sapma Star Trek'in sinema filmidir. Dolayısıyla ABD post-apokaliptik bilimkurgu sinemasında esas ideolojik yoğunlaşmanın liberal, merkezci ve muhafazakar siyaset arasında olduğunu çıkarsamak mümkündür.

Post-apokaliptik filmlerin temel sorunsallarından birisinin, hayatta hangi türden insanların kaldığı, kalması gerektiğidir. Başlangıçta hayatta kalmak 'seçilmiş' olmakla aynı şeyken, zamanla hayatta kalanlar rastgele bir özellik göstermeye başlamıştır ve hayatta kalanların arasındaki ayıklanma, geleceğe yön vermeye başlamıştır. Bu insan tipi cesur, fedakâr, becerikli, çeşitli silahları kullanabilen, naif, gerektiğinde acımasız, yeniliklere açıktır. 'Ayıklananlar' bunun zıddı tipte insanlardır ve temel düzeyde uygarlık dışında, ahlaki olarak zayıf, iktidar ve güç hastalığına tutulmuş kimselerdir. Bilim insanları, bilimkurgu filmlerinin geneli gözetildiğinde daha az temsil edilir. Felaketin niteliğine göre, robotlar, cyborglar türde kendini sıklıkla gösteren tiplerdir. Mutantlar ise felaket sonrasının kurbanları olsalar da radikal bir öteki olarak tehdit olarak kavranmışlardır.

Genel olarak filmlerin ikonografisine yön veren temel unsurlar, mekân olarak çölleşmiş, çorak boş mekânlar, boşaltılmış kent, kapatılmış yeraltı kentleridir. Bu mekânlar sonsuz özgürlük ile kasvetli biçimde kapatılmışlık duygusunu temsil etmektedirler; tekinsizdirler ve sınıfsal ayrışmaları gösterecek biçimde hiyerarşiktir. Dolayısıyla mekânın sınırlarına çıkmak zorunlu biçimde ihlal, kurallara karşı gelmektir. Sanal dünya ise ağırlıkla bir kaçış mekânı olarak anlam kazanmaktadır.

Filmlerde bilimkurgunun tematik bütün alttürleri kendine yer bulmaktadır. Yıkım olgusu bu dünyaya ilişkin bir olgudur ve temel ilgi alanı başka dünyalar ve evrenlerin 
niteliğinden çok, onların ne düzeyde bir tehdit içerdiğidir. Uzaylılar türde çok fazla yer almamaktadır.

Post-apokaliptik bilimkurgu türünün uylaşımlarını ve ideolojik yönelimlerini şu şekilde listelemek mümkündür:

- İnsan ve dünya felaketlere karşı kırılgandır ve bu felaket gerçekleşmiştir.

- İnsanın bilgi, teknoloji ve kültürü bu felaketi engellemeye yetmemiştir (büyük ölçüde de yetmeyecektir).

- Her biçimde bu felaketler temelde insanlık durumunun sonucu olan felaketlerdir.

- Felaket sonrası dünyada kalan canlılar onları kötü ve iyi yapan çeşitli özelliklere sahiptir. Bu özellikler onların hayatta kalmalarının/kalmamalarının en önemli sebebidir. Var oluş etik bir ilke çerçevesinde yapılandırılır.

- Bütün filmleri tek bir kıyamet ideolojisinin dışavurumu olarak görmek mümkün değildir. Her bir film apokaliptik vizyonunu hâkim bir makro ideolojiye göre şekillendirmektedir

- Felaket gerçekleşip, insanların önemli bir kısmı ortadan kalksa da bu dünyanın arınması ve yeniden bereketli bir yer olması için yeterli değildir. Kalanlar 'iyi' olduklarını ispat etmelidir, ancak bundan sonra 'kutsama' mümkün hale gelir.

- Kutsama için son savaş ve mücadele gereklidir. Yönlendirici norm aşkın bir temelden kaynaklanır.

Bu uylaşımlar ve özellikler kuşkusuz 'mutlak' değildir ancak K. Koch'un "kıyamet ideolojisi" olarak listelediği özelliklerin pek çoğuyla uyumludur. Bununla birlikte uylaşımlar türün tarihsel gelişimi içinde müzakereye ve değişime açıktır. Dahası 'iyi' ve 'kötü' değerler, felaketin sebebi gibi olgular hemen her filme ve yaşanan dönemin konjonktürüne göre değişiklik arz etmektedir.

\section{Kaynakça}

Baudou, J. (2005). Bilim-Kurgu (Birinci Baskı) (İ. Bülbüloğlu, Çev.). Ankara: Dost.

Broderick, M. (1993). Surviving Armageddon: Beyond the Imagination of Disaster. Science Fiction Studies. 20(3), 362-382. Erişim adresi: http://www.jstor.org/stable/4240277.

Boz, M. (2018). 2000 Sonrası Amerikan Post-Apokaliptik Bilimkurgu Sinemasında Kıyamet Ideolojisi (Yayımlanmamış Doktora Tezi). Ege Üniversitesi Sosyal Bilimler Enstitüsü, İzmir.

Buckland, W. (2002). Film Studies. London: Hodder and Stoughton.

Bø, K. (2013). Surviving The End (Yayınlanmamış Yüksek Lisans Tezi). University of Tromsø, Tromsø.

Cevizci, A. (1999). Paradigma Felsefe Sözlüğü (Üçüncü Baskı). İstanbul: Paradigma

Chan, S. (2018, 25 Ocak). Doomsday Clock Is Set at 2 Minutes to Midnight, Closest Since 1950s. The New York Times. Erişim Adresi (28.01.2018): https://nyti.ms/2GiEPDU.

Crutzen, P. J. (2002). Geology of mankind. Nature, 415(3). Erişim Adresi (17.12.2017): http:// 
courses.geo.utexas.edu/courses/387H/PAPERS/Crutzen2002.pdf.

Collins, J. J. (1998). The Apocalyptic Imagination: An Introduction to Jewish Apocalyptic Literature (Second Edition). Cambridge: Eerdmans.

Collins, J. (2005). Apocalypse. L. Jones (Ed.), Encyclopedia of Religion (Second Edition) içinde (s. 409-414). Farmington: Thomson Gale.

Curtis, C. P. (2010). Postapocalyptic Fiction and Social Contract: "We'll Not Go Home Again". Lanham, Boulder, New York, Toronto, Plymouth, UK: Lexington.

Geraghty, L. (2009). American Science Fiction Film and Television (First Publishing). Oxford, New York: Berg.

Gernsback, H. (1929). Science Wonder Stories. Science Wonder Stories. New York. 1(1).

Giannetti, L. (2008). Understanding Movies (11. Edition). New Jersey: Pearson

Grossman, J. R. (2011). Keeping The Lights On: Post-Apocalyptic Narrative, Social Critque, and The Cultural Politics of Emotion (Yayımlanmamış Yüksek Lisans Tezi). Colorado State University, Colorado.

Enviroenment \& Society (2019). Erişim Adresi (12.04.2019: http://www.environmentandsociety. org/tools/timeline\#/id/3647

Edwards, L. E. (2015), What is the Anthropocene?, Eos, 96, Erişim (12.04.2019): doi:10.1029/2015EO040297.

Harris, E. A. (2016). The Post-Apocalyptic Film Genre in American Culture 1968-2013 (Yayımlanmamış Doktora Tezi). University of Leicester, Leicester.

McGinn, B. (1979). Visions of the End: Apocalyptic Traditions in the Middle Ages. New York: Columbia University.

Mishina, V. (2016). Imagining the End: Analysis of Post-Apocalyptic Genre (Yayımlanmamış Yüksek Lisans Tezi). Masaryk University, Brno.

Moon, H. (2014). The Post-Apocalyptic Turn: a Study of Contemporary Apocalyptic and PostAcpocalyptic Narrative. (Yayımlanmamış Doktora Tezi). The University of Wisconsin-Milwaukee, Wisconsin-Milwaukee.

Kermode, F. (2000). The Sense of an Ending. New York: Oxford University.

Oskay, Ü. (2014). Çağdaş Fantazya. Popüler Kültür Açısından Bilimkurgu ve Korku Sineması. İstanbul: İnkilap.

Özden, Z. (2004). Film Eleştirisi (2. Baskı). Ankara: İmge

Post-Apocalyptic, (2017). Oxford Living Dictionaries. Erişim Adresi (18.12.2017): https:// en.oxforddictionaries.com/definition/us/post-apocalyptic.

Roberts, A. (2006). Science Fiction. (Second Edition). London and New York: Routledge.

Roloff, B., ve SeeBlen, G. (1995). Ütopik Sinema. Bilimkurgu Sinemasının Tarihi ve Mitolojisi (Birinci Baskı)(V. Atayman, Çev.). İstanbul: Alan. 
Schlobin, R. C. (1981). Definitions of Science Fiction and Fantasy. M. B. Tymn (Der.), The Science Fiction Reference Book içinde (s. 496-511). Washington: Starmont House.

Seed, D. (2011). Science Fiction, A Very Short Introduction (First Published). New York: Oxford University.

Sobchack, V.C. (2001). Screening Space: The American Science Fiction Film (Second Edition, Fourth Printing). New Brunswick, New Jersey, London: Rutgers University.

Sobchack, V. (2005). American Science Fiction Film: An Overview. A Companion to Science Fiction (First Publish). D. Seed (Ed.). s. 261-274 içindewerb. Oxford: Blackwell.

Sontag, S. (2015). Yoruma Karşı (Birinci Basım). (O. Akınhay, Çev.). İstanbul: Agora.

Suvin, D. (1979). Metamorphoses of Science Fiction. New Haven and London: Yale University.

Telotte, J.P. (2004). Science Fiction Film. Cambridge: Cambridge University.

Werblowsky, R.J. Z. (2005). Eschatology. L. Jones (Der.), Encyclopedia of Religion Vol 4 (Second Edition) içinde (s. 2383-2386). Farmington: Thomson Gale. 